\title{
"Por conto e peso": o comércio de marfim no Congo e Loango, séculos XV - XVII'
}

\begin{abstract}
Mariza de Carvalho Soares ${ }^{2}$
RESUMO: $\bigcirc$ artigo descreve a implantação do comércio de marfim na costa centro-ocidental africana entre 1490 e 1620. Essa região tem sido estudada do ponto de vista do comércio atlântico de escravos, mas não existem estudos dedicados ao marfim. $O$ comércio do marfim bruto aparece na historiografia como referência passageira. Já a circulação do marfim lavrado tem sido estudada a partir de objetos encontrados nos museus europeus, ponto final de uma longa cadeia diplomática e comercial. Tomando como referência o comércio de marfim nos portos da costa do Congo e Loango, o texto estabelece o contexto africano de acesso ao marfim antes do crescimento do comércio de escravos na região, destacando sua importância no conjunto das atividades econômicas da época.
\end{abstract}

\section{PALAVRAS-CHAVE: Marfim. Loango. Comércio. Congo. África centro-ocidental.}

ABSTRACT: This article describes the organization of the ivory trade in West Central Africa between 1490 and 1620. The region has been scrutinized by scholars working on the Atlantic slave trade, but not on the ivory trade. Carved ivory studies, by the way, approach art objects that correspond to the end of a long chain of diplomatic and commercial exchanges, frequently without exact provenance and date of the referred objects. The paper focuses on the trade of raw ivory in Loango and Congo presenting the context of trade, and its commercial relevance among other commodities in order to demonstrate the importance of the ivory trade in those ports before the growth of the slave trade.

KEYWORDS: Ivory. Loango. Trade. Kongo. West Central Africa.
1. Este texto integra a pesquisa do meu projeto de produtividade do $\mathrm{CNPq}$ (2014-2017) e dialoga com grupo de pesquisa sobre marfins africanos, em que se integra, reunido no projeto "Marfins Africanos no Mundo Atlântico: uma reavaliação dos marfins luso-africanos", financiado através da FCT - Fundação para a Ciência e a Tecnologia, PTDC/EPHPAT/1810/2014, coordenado pelos professores José da Silva Horta (Universidade de Lisboa), Peter Mark (Wesleyan University) e Vanicleia Silva Santos (UFMG). Agradeço aos pareceristas da revista e a Joseph Miller pela leitura do texto, correções e sugestões enviadas.

2. Professora do Programa de Pós-graduação em História da UFF, curadora da coleção Africana do Museu Nacional e pesquisadora Id do CNPq. E-mail: <marizac soares@gmail.com>. 
3. Em 1841 foi publicada na França a Encyclopédie du commerçant. Seus verbetes foram escritos por diversos autores sob a direção geral de Gilbert Guillaumin, diretor da obra, que assinava apenas $\mathrm{M}$. (monsieur) Guillaumin. Para efeitos de citação, indico a direção da obra: Guillaumin (1841, p. 1.213); Bluteau (1712-1728. v. 5); Silva, Antonio Moraes e (1813, v. 2).

4. No sítio arqueológico de Valencia de la Concepción (Sevilha, Espanha) foi encontrada uma oficina onde se trabalhava marfim de elefante asiático na primeira metade do terceiro milênio antes da era comum. Ver Calvo et al. (2013, p. 1579-1592).

5. Guillaumin (1841, p. 1.213).

6. Zurara (ou Azurara) foi cronista da Casa de Bragança. Zurara (1973). António Brásio, editor da maior compilação de documentos africanos, transcreve esse trecho e anota que Zurara tinha conhecimento do comércio de marfim, feito pelos árabes no Marrocos. Brásio (19811988). A obra referida está composta em três séries (I, II, III), com volumes no interior de cada série $(1,2,3)$, e em cada volume há documentos numerados (doc. 1). A citação completa das três séries está nas referências. $\mathrm{O}$ comentário citado está em $M M A-I I$, v. 1, doc. 7 , nota 4, p. 30.

7. As primeiras remessas de marfim africano para a Índia datam pelo menos de 1505 , quando os portugueses instalaram uma feitoria na Ilha de Moçambique. Esse comércio se manteve ao longo do tempo. Para o século XVI, ver Axelson (1973).

8. Usa-se também o termo marfim para os dentes de hipopótamo que chegam a pesar 3 quilos e apresentam um marfim muito branco que não escurece. Ver
Introdução

Até o século XIX dava-se o nome de marfim (ivoire, ivory) apenas aos segmentos de dentes de elefante, fossem eles brutos ou lavrados. $\bigcirc$ dente inteiro e o osso da mandíbula eram chamados "marfil". A palavra marfil deriva de fil, que em árabe quer dizer elefante. ${ }^{3}$ Desde a Antiguidade há registro da presença de marfim de elefante africano na Europa, indicando sua inserção no comércio transcontinental através do Mediterrâneo. ${ }^{4}$ No Renascimento o marfim foi uma matéria-prima pouco explorada e só a partir do século XV voltou a ser valorizado, especialmente na França. Dieppe (porto francês da Normandia) abastecia grande parte da Europa com mercadorias ultramarinas, inclusive o marfim africano. ${ }^{5}$

Cronista português Gomes Eanes de Zurara (1410-1474) narra as primeiras décadas da exploração da costa africana. Descreve os elefantes, sua carne e os artefatos feitos com seu couro, assinalando que "os ossos não se aproveitam em nenhuma coisa, antes os lançam longe". Assim, já no início da era moderna, o marfim africano entra regularmente em Portugal, através do circuito atlântico. ${ }^{\circ}$ Complica sua identificação e percursos o fato de boa parte das esculturas vindas de Goa ser lavrada com marfim de Moçambique. ${ }^{7} \bigcirc$ marfim costuma ser classificado em vários tipos segundo o tamanho, a cor (e mudança de cor), a densidade e condições de preservação (ressecamento). A Europa preferia o marfim bruto africano por ser mais claro, menos denso e amarelar menos que o asiático, facilitando o entalhe e polimento. ${ }^{8}$ Segundo a Encyclopédie du commerçant, o marfim da costa atlântica africana costuma ser dividido em dois grupos: o marfim do Senegal, que geralmente é branco, mas que frequentemente apresenta rachaduras em consequência das condições do clima e transporte (como o marfim do Egito); ${ }^{9}$ e o marfim da Guiné (Serra Leoa e rio Benim), o mais procurado.

A Encyclopédie du commerçant menciona ainda uma terceira área que chama de "Angola", à qual dá pouca atenção. Na costa atlântica centro-ocidental os grandes dentes (vindos da savana) são mais raros; ali se encontram com mais facilidade dentes de elefantes da floresta medindo, em média, dois ou três pés (entre 60 e 90 centímetros). Na verdade, Angola nunca foi um importante fornecedor de marfim; o fornecimento se concentrava nos portos ao norte do rio Zaire, sendo o principal deles o Loango. ${ }^{10}$ Esse artigo mostra que o mais acurado é falar em três e não em duas grandes áreas de comércio e produção de objetos de marfim na costa atlântica africana. A terceira, que aqui demarco como a costa do Loango e Congo (parte do Gabão, República Popular do Congo, República Democrática do Congo e Angola), tem sido menosprezada.

Sobre a arte africana em marfim, merecem destaque os trabalhos de William Fagg. ${ }^{11}$ Na sequência, Ezio Bassani e outros vêm dando continuidade ao tema, sob diferentes abordagens. Detenho-me aqui aos trabalhos dos historiadores Peter Mark e José Horta. ${ }^{12} \bigcirc$ trabalho desses autores se concentra no estudo de objetos de marfim encontrados na Europa, ponto final de uma longa cadeia diplomática e comercial que levou o marfim africano aos consumidores e 
colecionadores europeus. Curiosamente, o comércio do marfim não despertou o interesse dos historiadores africanistas que vêm se dedicando ao circuito comercial do ouro, dos escravos, dos tecidos e de outras mercadorias. Meu propósito neste artigo é justamente estabelecer o contexto de acesso ao marfim na costa do Loango e Congo, da chegada dos portugueses ao início do século XVII.

Do ponto de vista da história do continente africano, o texto preenche uma lacuna historiográfica. Autores consagrados da historiografia africanista com obras que analisam a presença europeia na África centro-ocidental no período aqui abordado, como David Birminghan, Ann Hilton, Phillys Martin e Jan Vansina, abordam tangencialmente o tema. Essa pouca atenção deriva não de um descaso, mas do recorte estabelecido por esses autores que privilegiam o impacto (maior ou menor) do comércio de escravos junto aos povos africanos. ${ }^{13}$

Em 1482, por ocasião da construção do Castelo da Mina latual Gana), os negócios ali estabelecidos pelos portugueses já abarcavam ouro, marfim e escravos. ${ }^{14}$ No mesmo ano o explorador Diogo Cão chegou ao rio Zaire. Os relatos das primeiras expedições ao chamado "Reino do Congo" iá fazem referência ao marfim bruto e lavrado, indicando a presença de artesãos/ artistas especializados, antes da chegada dos portugueses. Rui de Pina, cronista que sucedeu Zurara na corte portuguesa, descreve os primeiros presentes enviados pelo "rei" do Congo ao rei de Portugal, entre eles, "dentes de elefante" e "coisas de marfim lavrado". 15

No século XVI o marfim bruto e lavrado circulava em toda a Europa. ${ }^{16}$ Data de 1531 uma carta do doutor Gaspar Vaz, enviado português à corte francesa, que informa a D. João III de Portugal sobre a chegada a Rouen de uma nau francesa carregada de malagueta, algodão, couros, 150 quintais de marfim (cerca de 8 toneladas) e outras mercadorias obtidas ao sul da llha de Cabo Verde, ponto limite de trânsito das embarcações francesas, segundo o acordo com os portugueses. ${ }^{17}$ Essa carta indica o interesse tanto português quanto francês pelo comércio do marfim na ocasião. Na França, as mercadorias trazidas do ultramar eram repassadas para embarcações menores que subiam o Sena. Roven, cidade da Normandia às margens do Sena, foi um dos portos de desembarque do comércio ultramarino com destino à França e outros países. De Roven se fazia também comércio com Espanha e Portugal. Sob a alegação de que as mercadorias vinham "de terras que notoriamente eram de Vossa Alteza", Vaz pede, sem sucesso, o embargo da carga e sua restituição a Portugal. ${ }^{18}$ Não seria de estranhar se o marfim desembarcado tivesse vindo da foz do rio Zaire. Já em 1526 o Mani Congo Nzinga Mbemba (rei do Congo) informara D. João III sobre a chegada de franceses ao porto de Pinda para negociar marfim, manilhas (argolas de metal) e tacula (madeira vermelha usada como tintura) com o Mani Sonho (conde do Sonho), seu vizinho. ${ }^{19}$

No início do século XVII a demanda europeia por marfim cresceu significativamente. As oficinas europeias produziam estatuetas seculares e religiosas, medalhões, objetos utilitários como cabos de facas, pistolas, caixas de rapé e até
Guillaumin (1841, p. 787) e Hecht (2000).

9. Guillaumin (1841, p. 1.213).

10. Por esse motivo as presas esculpidas do Loango são geralmente pequenas. $\mathrm{Na}$ página do Brooklyn Museum consta um dente lavrado de $99,1 \mathrm{~cm}$ de comprimento (número 35.679), identificado como Vili (comerciantes do Loango). Há de se distinguir entre as presas da floresta e as da savana, através da floresta, trazidas pelas caravanas Vili. Não encontrei imagens ou descrições de marfim lavrado no Loango no século XVII. As presas lavradas identificadas como o Loango têm um trabalho em espiral bem característico, mas todas que vi até agora estão datadas como séculos XIX e XX.

11. Sobre a arte indo-portuguesa e afro-portuguesa, ver Fagg (1958) e, mais recentemente, Bassani; Fagg (1988).

12. Peter Mark (2003), Luís Urbano Afonso e José da Silva Horta (2013) têm destacado a importância da produção de peças de marfim na Serra Leoa.

13. Ver Birminghan (2004), Ferreira (2003), Hilton (1985), Martin (1972), Miller; Thornton (1987), Postma (1990), Filipa Ribeiro da Silva (2011), Sommerdyk (2012) e Vansina (1990). Sommerdyk faz um balanço da historiografia da costa do Loango, confirmando a ausência de atenção ao tema.

14. Segundo João de Barros (1496-1570), nessa ordem de prioridade. Em 1521 João de Barros foi nomeado capitão da Fortaleza de São Jorge da Mina; em 1625 tesoureiro da Casa da Mina; e em 1532 feitor da Casa da Índia e Mina; foi também autor da primeira história das conquistas portuguesas. (Ásia), aqui citada a partir 
Brásio (MMA-I, v. 1, doc. 5, p. 18). Em 1482 a família Abravanel obteve o monopólio do comércio de escravos naquela costa e já então se fazia comércio clandestino: José Negro e Eleázar Navarro importavam escravos, ouro e marfim. Ver Mendes (2008).

15. Os termos "reino" e "rei" são pouco adequados às sociedades africanas e seu uso tem sido criticado pela historiografia africanista. Em língua inglesa os termos usuais são "polity" e "ruler". Como alternativa uso unidade política (com ou sem governo unificado estabelecido) e governante. Uso em alguns momentos os termos reino e rei quando esses termos remetem o texto diretamente à documentação portuguesa da época. Rui de Pina tornou-se oficialmente cronista em 1497, mas desde 1490 atuava como tal. Pina (1790/92).

16. Há ainda hoje uma grande carência de informações sobre a existência e o funcionamento de oficinas de marfim em Portugal, entre os séculos XV e XVII. Em pesquisa recente, Vitor Serrão encontrou referência a um João de Paris que fazia relógios de marfim "em sua tenda no Arco dos Pregos", em Lisboa. Tudo indica que era uma arte pouco praticada em Portugal. Documento do ANTT cedido por Vitor Serrão a José Horta (2016). Agradeço a José Horta a informação. A maior parte da arte em marfim encontrada em Portugal é uma arte religiosa, sendo que entre as coleções mais significativas estão os crucifixos, geralmente datados do século XVIII. Segundo informação verbal de Isabel de Sá, a devoção ao Cristo crucificado (por extensão o uso de crucifixos) se propaga em Portugal já na virada do século XVIII. A leitura do Santuário Mariano estende a não utilização do marfim para as imagens de Nossa dentes postiços. ${ }^{20} \mathrm{Na}$ segunda metade do século XVIII, Dieppe tornou-se o maior centro de produção de objetos de marfim da Europa. ${ }^{21}$ Mesmo assim não se compara o comércio do marfim com o do ouro, a mercadoria mais cobiçada no comércio do ultramar africano. Segundo o historiador Johannes Postma, estudioso do comércio holandês, na segunda metade do século XVII cerca de $75 \%$ dos negócios da WIC, criada em 1621, eram em ouro. Em segundo lugar vinha o marfim que representava 5\% do total das importações holandesas da Africa. ${ }^{22} \mathrm{Na}$ primeira metade do XVII, e antes disso, esses números foram certamente muito inferiores, o que permite estimar que a importância proporcional do marfim teria sido então bem maior. ${ }^{23}$

Exemplos da presença do marfim em objetos de luxo para uso e adorno são a Vênus e Cupido (1620-1624), de George Petel, hoje pertencente à coleção do Ashmolean Museum (Oxford), e uma caneca (1662-1696) da coleção do The Victoria Albert Museum (Londres). ${ }^{24}$ A questão que se coloca é como combinar essas valiosas coleções dispersas em museus de todo o mundo com os dados disponíveis sobre a circulação de martim bruto e lavrado, entre os séculos XV ao XVII. A grande maioria dos objetos hoje encontrados foi produzida com marfim africano em oficinas europeias, por artesãos e artistas europeus; em nada se aproximam dos objetos trazidos da África como os presentes do Mani Congo ao rei de Portugal, ou aos olifantes e saleiros da arte denominada "afroportuguesa" ou "luso-africana". 25

Ao tratar do terceiro segmento da costa africana que, ao entrar no circuito atlântico do marfim que a Enciclopédie du commerçant denominou "Angola", concentro-me no trecho da costa que abarca uma vasta região usualmente identificada como Congo. Na verdade, é preciso circunscrever ainda mais essa área que abarca um vasto território que ultrapassa as fronteiras do Congo e que, do ponto de vista demográfico e cultural, constituise a partir de uma longa sequência de levas migratórias que atingiram diversos pontos da costa atlântica. A mistura desses povos migrantes com outras populações locais já aí estabelecidas fez surgir, a partir do século Xl, uma série de pequenas unidades políticas já envolvidas nas rotas do sal, cobre e ferro do litoral que também comerciam marfim. ${ }^{26}$ Foi através desses comerciantes locais que os portugueses entraram em contato com o marfim bruto, no século XV. Essa longa faixa do litoral vai do Cabo Lopez até o norte de Angola e estava dividida em pequenas unidades políticas e territoriais cuja influência sobre seus vizinhos variou ao longo do tempo. Entre elas duas mereceram maior destaque: Kongo e o Lwango, ou o "Reino do Congo" e o "Reino do Loango".

Ao norte do Zaire ficavam o Loango (porto do Loango), Cacongo (porto de Malemba), Ngoyo (porto de Cabinda); e ao sul o Congo e Sonho (porto de Pinda). $O$ acesso ao Congo era feito por mar, através de Pinda. ${ }^{27}$ Nas narrativas de exploração da costa nas duas últimas décadas do século XV, apenas o Congo é citado. Inicialmente os portugueses ali se estabeleceram, descendo depois em 
direção ao Ndongo (Angola), que ficava fora do circuito preferencial do marfim. $\bigcirc$ Loango nunca chegou a estar na jurisdição portuguesa. Ao longo do século XVII todos esses portos passaram a ser exportadores de escravos, mas não deixaram de exportar marfim e outros produtos. ${ }^{28}$

A maior parte das informações hoje disponíveis sobre a caça do elefante e o comércio do marfim no século XVI resulta de relatos sobre o Loango e não sobre - Congo. A primeira descrição da caça ao elefante é feita por Samuel Brun (Braun), um cirurgião que viajou ao Loango em 1611 a serviço de uma embarcação holandesa. Brun informa que os caçadores buscavam os caminhos regularmente percorridos pelos elefantes e neles faziam grandes buracos (com a profundidade da altura de dois homens), que eram cobertos com folhas. Depois esperavam e, quando os elefantes caíam, eles imediatamente lançavam sobre eles suas azagaias e retiravam as presas. ${ }^{29}$

A partir das narrativas dos séculos XV e XVI, a primeira parte do artigo propõe uma conceituação das modalidades de circulação do marfim, seja ele bruto ou lavrado; a segunda aborda aspectos do comércio português de marfim na costa centro-ocidental no século XVI; a terceira trata da entrada do Loango no comércio do marfim no final do século XVI e o crescimento desse comércio já nos primeiros anos do século XVII, antes da entrada do Loango no circuito do comércio de escravos; e a quarta mostra o comércio do marfim no Loango, contrapondo a presença dos holandeses ali instalados aos portugueses sediados em Angola.

\section{A circulação do marfim no Congo}

Alvise Cadamosto, considerado o descobridor das llhas de Cabo Verde e de parte da então chamada Costa da Guiné, fez duas viagens à costa africana a mando de D. Henrique, em 1455 e 1456. ${ }^{30}$ No relato de sua segunda viagem informa que um "dente de doze palmos de comprido" e um "pé" de elefante foram por ele mandados de presente ao Infante D. Henrique, que os ofereceu sua irmã, princesa Isabel (1397-1471), já então Duquesa de Borgonha. ${ }^{31}$ Considerado o palmo de 22 centímetros, o dente deveria medir cerca de 2,64 metros, um dos maiores de que se tem notícias. Um dente de marfim africano pode chegar a mais de 10 pés de comprimento ( 3 metros) e pesar mais de 200 libras (90,72 quilos). ${ }^{32}$

Nos anos do reinado de D. João II (1481-1495) os portugueses construíram o Castelo da Mina (1482) e, passando pelo rio Benim, chegaram à tha de São Tomé e à foz do rio Zaire. Dois cronistas do reinado de D. João II deixaram relatos sobre o tema: Garcia de Resende (1470-1536) e o já mencionado Rui de Pina (1440-1522). Ambos foram próximos a D. João II e seus relatos possivelmente têm, pelo menos em parte, as mesmas fontes. ${ }^{33}$ Ambos descrevem objetos de marfim lavrado (trombetas e braceletes). ${ }^{34}$
Senhora. Um levantamento de sete dos dez volumes do Santuário Mariano (um inventário das devoções marianas no Império Português feito no século XVII) me levou a constatar a ausência quase absoluta de imagens da Virgem em marfim. Apesar dos problemas no uso dessa fonte acredito ser confiável a descrição física das imagens encontradas. Santa Maria (1642-1728).

17. D. João III governou de 1521 a 1557 . Considerando o quintal das Ordenações Manuelinas (1 quintal $=4$ arrobas $=58,752$ quilos) seriam $8.812,8$ quilos.

18. Carta (1531).

19. Brásio (MMA-I, v. 1, doc. 144 , p. 476 ).

20. Guillaumin (1841, p. 737).

21. Entre seus artistas destacou-se o pioneiro Jean Mançel (em atividade entre 1681 e 1717). O Chateau de Dieppe possui a maior coleção de marfins da Europa (Mallalieu, 1999). O bombardeio infringido pelos ingleses em 1694 destruiu a cidade, acabando com sua projeção comercial e abalando fortemente as oficinas de artesanato em marfim. Ver Guillaumin (1841, p. 1.213).

22. Postma (1990, p. 85) Para obras recentes sobre o comércio holandês, ver Filipa Ribeiro da Silva (2011) e Sommerdyk (2012).

23. Para a precariedade das tentativas de acesso direto ao ouro na região do Castelo da Mina, ver Deveau (2005).

24. Para Ashmolean Museum: <http://www.ashmoleanprints.com/image/383241/ georg-petel-venus-and-cupid>; para o Albert Museum: $<$ http://collections.vam.ac. uk/item/O164154/ivory-tankard-in-silver-gilt-tankard-hering-hans-heinrich/>. 
25. Sobre esse debate conceitual, ver Mark (2007).

26. Bostoen et al. (2015).

27. Esses são os nomes dados pelos portugueses aos portos. Os portugueses chamavam Mani Sonho de "conde"; o Mani Congo e o Maloango eram chamados de "rei". O conde do Sonho era considerado vassalo (rebelde) do rei do Congo. A atribuição de títulos aos governantes africanos é usual entre os portugueses e mostra como eles manipulam os conflitos locais e legitimam alguns governantes em detrimento de outros, em seu benefício. Sobre o governo de Nzinga Mbemba (ca. 1456-1542/43) batizado D. Afonso I, ver Hilton (1985, p. 53-65). Agradeço a Joseph Miller a sugestão dessa nota.

28. Angola abarca boa parte do antigo território do Kongo e o enclave de Cabinda, onde ficavam o Kakongo e Ngoyo. Em 1882 o Loango foi incorporado ao Congo francês e o território do antigo reino fica hoje no departamento de Kouilou, cuja capital é Loango, na República do Congo, conhecida como Congo Brazzaville.

29. Samuel Brun (15901668). Nascido em Basel (Suíça), deixou um relato sobre sua estadia na costa africana editado e publicado por Jones (1983, p. 54-55).

30. A obra de Luiz de Cadamosto é composta de três relatos: "Navegação primeira de Luiz de Cadamosto"; "Navegação segunda de Luiz de Cadamosto"; e "Navegação do capitão Pedro de Cintra, portuguez, escrita por messer Luiz de Cadamosto". Cito aqui a segunda narrativa. Cadamosto (1812, p. 68).

31. Cadamosto (1812, p. 68). Sobre a duquesa, ver Taylor (2001). Sobre a duquesa de Borgonha, o mar-
Rui de Pina narra a conversão de Caçuta (chamado "fidalgo" do reino do Congo) e os presentes por ele levados a Portugal: "O presente do dito rei do Congo para el rei era de dentes de elefantes, e coisas de marfim lavradas, e muitos panos de palma bem tecidos, e com finas cores". Garcia de Resende descreve "um presente de muitos dentes de elefantes e coisas de marfim lavradas, e muito panos de palma bem tecidos, e com finas cores". ${ }^{35}$ Já batizado e usando o nome de D. João da Silva, Caçuta volta ao Congo e testemunha diante de seu rei o que vira e aprendera em Portugal. ${ }^{36} \mathrm{Em}$ troca desses presentes, D. João envia arcas cheias de objetos valiosos: "muitos e ricos ornamentos e cruzes; castiçais e galhetas campainhas e sinos; e órgão; muitos livros; e todas outras coisas necessárias para igrejas tudo em muita perfeição". ${ }^{37}$

Rui de Pina narra outras duas cerimônias ocorridas em 1491: a primeira foi preparada pelo Mani Sonho para receber a expedição de Rui de Souza que desembarcou em Pinda para dali seguir para Ambasse, capital do Congo, onde residia o Mani Congo. A segunda, na sequência da mesma viagem, foi a entrada de Rui de Souza em Ambasse, onde foi recebido pelo Mani Congo. Sobre os festejos no Sonho, diz: "e para isso se ajuntou logo muita gente com arcos e flechas e com atabaques e trombetas de marfim e com violas, tudo segundo seu costume". Sobre a entrada em Ambasse descreve um cortejo "com muitas trombetas de marfim e atabaques...". ${ }^{38}$ Garcia de Resende descreve a mesma cerimônia, como a entrada dos "cristãos" na corte do Congo, menciona "muitas trombetas marfim" e descreve o rei:

...posto em um estrado rico, e nu da cintura para cima, com uma carapuça de pano de palma, e ao ombro um rabo de cavalo guarnecido de prata, e da cinta para baixo coberto com panos de damasco, que el rei [de Portugal] Ihe mandara, e do braço esquerdo um bracelete de marfim. ${ }^{39}$

Os cortejos são parte prática política e diplomática que se consolida no reinado de D. João III (1521-1557) como uma forma de propaganda real. É difícil estabelecer o que há de práticas cerimoniais anteriores à chegada dos portugueses e o que, nessas cerimônias diplomáticas, resulta dos primeiros anos do contato. De um modo ou de outro os cortejos no Congo contribuíram para isso. Diferentemente de práticas cerimoniais - que podem ser rapidamente adotadas -, os presentes, e em especial os tecidos e instrumentos musicais, são fruto de um uso cultural que resulta de um longo processo de aprendizado técnico, artesão/artistas especializados.

Uma curiosidade fica por conta da descrição do trono do rei do Congo. João de Barros descreve o trono como "cadeira de marfim com algumas peças de pau lavradas" colocada sobre um "cadafalso" de madeira. ${ }^{40}$ Nos relatos de Rui de Pina e Garcia de Resende não há referências a cadeiras ou tronos de marfim, o que deixa em aberto a fonte de João de Barros. Já no final do século XVII o padre Francisco de Santa Maria (16531713), cronista da Ordem de Santo Elói, registrou sua viagem ao Congo. 
Segundo sua crônica o rei se sentaria "em uma cadeira de marfim, colocada sobre um trono de madeira". ${ }^{41}$ Ele poderia ter visto a cadeira, ou ter repetido a descrição de João de Barros. Não há, portanto, nos registros coevos qualquer certeza da existência de uma cadeira ou trono de marfim. Se essa cadeira existiu no século XVII pode ter sido uma inovação decorrente da própria valorização do marfim no mercado local.

Essa diplomacia se renova ao longo do tempo, mas as trocas passam a apresentar um perfil mais delimitado. Um regimento do rei D. Manoel a Simão da Silva (que vai de viagem ao Congo em 1512) mostra bem como essa diplomacia se regulamenta ao longo dos anos. Esse regimento é escrito em duas partes. A primeira trata da troca de cartas e presentes entre o Mani Congo Nzinga Mbemba (batizado D. Afonso I), enquanto a segunda introduz regras para embarques de mercadorias, em especial marfim e escravos. ${ }^{42} \bigcirc$ regimento inicia recomendando:

Tanto que em boa hora chegardes onde el Rei de Manicongo estiver, the dareis nossas cartas que para ele levais e nossas encomendas e saudações. As quais the direis que the enviamos por vós, assim como as costumamos dar e enviar aos Reis e príncipes cristãos, como muitos louvores sejam dados a nosso Senhor ele é, porque a reis e príncipes infiéis e que não são cristãos não enviamos encomendas nem saudações, segundo que disso fui informado para tho mais largamente falardes.

Depois de thes terdes dadas nossas cartas, logo então, se o tempo der lugar para isso e se não, logo ao outro dia seguinte, the apresentareis e dareis todas as coisas que the enviamos, que leva Álvaro Lopes, o qual convosco juntamente e assim o seu escrivão serão ao dar delas, para abrirem as arcas em que vão e vós the direis como tudo the enviamos com muito amor e boa vontade, com a qual sempre com todo o que houver em nossos reinos folgaremos The prestar, como Rei a que temos muito grande amor e que estimamos por sua virtude, como ele o merece e é razão. ${ }^{43}$

$\bigcirc$ regimento fala em cartas, saudações e encomendas, entre elas objetos litúrgicos de ouro e prata e alfaias para a capela que D. Afonso I mandara construir; feito isso, determina que Simão da Silva passe imediatamente ao carregamento dos navios:

E posto que nosso principal fundamento seja servir a nosso Senhor e a ele fazer prazer, como a rei cristão a que temos muito amor, vós como de voso [sic] the lembrar o que ele nisto deve fazer, como the haveis sempre de lembrar o que for de sua honra e de seu serviço; e trabalhareis como logo se comece a entender na carga dos navios e do que ele para isso houver de dar, assim de escravos como de cobre e marfim; e tudo isto the direis como de vosso, sem the dizerdes coisa alguma de nossa parte, trabalhando o mais honestamente que vós puderdes, como destas coisas venham o melhor carregados que seja possível; e faze-o assim bem, como de vós confiamos; e carregados os navios, dai aviamento à sua partida, abastecendo de mantimento da terra, além de biscoito que para a torna-viagem levais e assim da água para os escravos, em tal maneira que não possam os escravos correr risco à mingua disso, despachando de lá os ditos navios o mais breve que vós puderdes e em tal maneira que possam vir em bom tempo a estes reinos em boa hora, e principalmente venham bem carregados de escravos e das outras coisas... ${ }^{44}$ fim e os presentes "exóticos" da corte portuguesa, ver Simões (2014, p. 251).

32. Hecht (2000). Segundo a Encyclopédie du commerçant, seriam nove pés de 125 e 200 libras. Guillaumin (1841, p. 1.212).

33. Garcia de Resende foi também poeta, músico, desenhista, arquiteto e editor. Em 1490 já era considerado próximo a D. João II; em 1491 foi designado seu secretário particular, cargo que exerceu até o falecimento do rei em 1495. Em 1554 Garcia de Resende publicou a crônica onde descreve o contato dos portugueses com o reino Congo. Resende (1752). Para o texto de Pina, ver: Pina (1790/92, p. 5-204).

34. Sobre presentes enviados por D. Afonso, rei do Congo, ao rei de Portugal, ver Thornton (2002a, p. 9).

35. Embora os presentes exóticos já fossem uma prática da monarquia portuguesa desde o Medievo, foi a partir de D. Manoel I (1495-1521) que essa prática se exacerbou. Simões (2014). Sobre os cortejos, ver Alves (1986).

36. Pina (1790/92, p. 148$)$; Resende (1752, p. 68). Para a arte do Congo e os tecidos de ráfia, ver Bassani (1983).

37. Resende (1752, p. 69).

38. Pina (1790/92, p. 152 , 160).

39. Resende (1752, p. 70).

40. Barros (1778, p. 230, v. 1).

41. Para Battell, ver Ravenstein (1901, p. 109). Para João de Barros (O ceo aberto na terra. História das sagradas congregações dos cônegos seculares de $S$. Jorge...), ver Brásio (MMA$-I$, v. 1, doc. 21, p. 82). Para Francisco de Santa Ma- 
ria, ver Brásio (MMA-I, v. 1, doc. 23, p. 94).

42. O "regimento" é um instrumento da administração portuguesa usado em várias ocasiões. Governadores e outros oficiais régios tinham regimentos de modo a regulamentar sua atuação na administração do Império. Como é uma documentação diretamente associada ao cumprimento de tarefas estabelecidas, costuma dar um bom panorama das expectativas da Coroa em relação ao trabalho de seus súditos.

43. Regimento de D. Manoel a Simão da Silva, 1512. Brásio (MMA-I, v. 1 doc. 65, p. 231).

44. Brásio (MMA-I, v.1, doc. 65 , p. 239).

45. Brásio (MMA-I, v. 1, doc. 65 , p. 240 ).

46. Brásio (MMA-I, v. 1, doc. 65 , p. 239-240).

47. O arquipélago foi descoberto em 1471. De 1485 a 1522 teve seis donatários e em 1573 voltou à administração da Coroa. Henriques (2000); Guimarães (2009).
Esse regimento trata do conjunto das trocas entre Portugal e Congo e normatiza suas práticas, aí incluídos presentes, cartas, saudações, encomendas e compensações de gastos que o rei de Portugal alega ter com o Congo e seus súditos, seja no Congo, seja em Portugal. Essas compensações devem ser pagas em bens valiosos (como marfim e cobre). É importante entender tratar-se de um tipo de troca, mas não de comércio. O comércio lou como na época se dizia, "o resgate") foi proibido pelo Mani Congo. A compensação é parte do acordo diplomático, nada tem a ver com a atuação (malvista) dos comerciantes portugueses junto aos comerciantes locais. A diferença entre essas duas modalidades de troca fica mais evidente quando considerados os carregamentos: no carregamento de presentes o Mani Congo escolhe bens de valor a seu critério (marfim bruto ou lavrado, cobre, escravos, tecidos etc.); já a compensação atende à demanda portuguesa (nesse caso, como mostra o regimento o alvo são os escravos e o cobre).

Embora a palavra compensação não seja usada na documentação da época, seu sentido fica claro quando D. Manoel recomenda que Simão da Silva explique ao Mani Congo sua necessidade:

[...] e lembrando-the a grande despesa que fazemos com a enviada destes navios, frades e clérigos e coisas que the enviamos e que já antes de vós foram, e assim a despesa que se cá faz na mantença e ensino de seus filhos, por onde ele deve carregar os ditos navios o mais abastadamente que ele puder e de maneira que nós tenhamos ainda mais razão de fazer bem as coisas, como fazemos, posto o que vós sabeis certo o que nosso intento e lembrança não é de haver proveito de fazenda, somente do acrescentamento da fé. ${ }^{45}$

A compensação estabelecida no Regimento de 1512 é uma saída para a proibição do resgate. Como admitia D. Manoel no próprio regimento: "por saberdes que ele (o Mani Congo) o não consente", ou seja, o rei do Congo não permitia o resgate. ${ }^{46} \bigcirc$ fato de ser proibido indica que já então o comércio se fazia com regularidade e a principal mercadoria eram os escravos.

Se no Congo o comércio se fazia burlando o controle do Mani Congo, em São Tomé ele acontecia ao largo do controle da alfândega portuguesa. Desde os primeiros contatos, a presença de comerciantes vindos de Portugal ou de São Tomé estabelece uma rede comercial que foge ao controle régio. Em 1485 D. João Il introduz o sistema de capitania na costa centro-ocidental. São Tomé, sede da capitania, abarcava o arquipélago e toda a costa desde a foz do Níger até Angola, aí incluídas as ithas do Corisco e Ano Bom. ${ }^{47}$ Ainda em 1485, D. João publica uma carta régia sobre os privilégios dos povoadores de São Tomé, que trata dos resgates nos cinco rios além da Mina, conhecidos como "rios dos escravos" (ao sul do delta do Níger). Já nessa época iniciam-se as disputas entre os comerciantes de Lisboa e os comerciantes sediados na vila de Santo António, sede da capitania. As tensões entre eles - e entre os próprios comerciantes de São Tomé que disputam entre si os vários trechos da costa - foi uma constante desde então. Entre as mercadorias mais procuradas estava o marfim. 
Álvaro de Caminha foi o capitão de São Tomé que organizou a capitania. Faleceu em 1499, deixando Pedro Álvares de Caminha, seu sobrinho e auxiliar direto, informalmente em seu posto. Morto o tio, alegando valiosos serviços, o sobrinho escreveu ao rei pleiteando sua confirmação como novo capitão. Os serviços teriam sido prestados não na administração da capitania, mas "especialmente no mar, descobrindo muitos rios novos, em os quais há muitos escravos e muito marfim". ${ }^{48}$ Essas descobertas teriam beneficiado o pretendente ao cargo e também alguns dos armadores da ilha. Em 1516 eles são acusados de violar as condições do contrato e enviar ao rio Benim (onde se fazia resgate de escravos) uma embarcação de 120 toneladas. Segundo a denúncia, a embarcação de lá retornara cinco ou seis meses depois com 400 escravos, 100 quintais de marfim (5,9 toneladas) e outras mercadorias. ${ }^{49}$

Esses 100 quintais de marfim e certamente muitos outros já então atendiam à demanda europeia do produto ali comercializado lado a lado dos escravos, sem as restrições encontradas no Congo, na mesma época. Enquanto no Congo o comércio envolve relações diplomáticas entre o rei de Portugal e o Mani Congo, nos chamados "rios dos escravos" o comércio é feito pelos comerciantes portugueses, submetidos apenas ao contrato português, sem maiores embaraços diplomáticos. A distinção entre compensação e comércio estabelecida no regimento de 1512 ajuda a entender que o local de resgate mais procurado pelos armadores de São Tomé era, portanto, a área dos "rios dos escravos" (entre eles o rio Benim), onde se fazia mais comércio e menos diplomacia.

Essa complicada arquitetura legal-diplomático-comercial sustenta a hipótese de que, na virada do século XV para o XVI, o comércio do marfim se fazia preferencialmente no Benim; enquanto no Congo (não considerado o contrabando, impossível de estimar) predominavam as compensações. Nos dois casos o marfim é levado a São Tomé para ser contado, pesado e depois enviado à Casa da Mina, em Portugal. Um estudo mais aprofundado desse comércio pode ajudar a repensar o comércio do marfim bruto no rio Benim, assim como a comercialização de peças de marfim lavrado, trazendo novas informações para repensar os estudos de William Fagg sobre a produção de marfim lavrado do Benim no século XVI. ${ }^{50}$

Por fim, presentes, compensações e comércio não foram etapas das relações entre Portugal e os chamados "reinos" africanos. São diferentes modalidades de troca que ocorreram ao mesmo tempo e em diferentes proporções. Enquanto presentes e comércio são práticas reconhecidas em toda a costa, a compensação precisa ser estudada mais a fundo para se ter uma ideia de sua ocorrência.

O marfim no comércio português do Congo e Angola

O já referido regimento de D. Manoel a Simão da Silva (1512) mostra como, nos primeiros anos do século XVI, estabelece-se e se regulariza o comércio de escravos, cobre e marfim no Congo. Primeiro o regimento manda Simão da
48. Brásio (MMA-I, v. 1, doc. 42, p. 167)

49. "Inquirição". Brásio (MMA-I, v. 1, doc. 105, p. 372).

50. Afonso; Horta (2013, p. 22, nota 1), Mark (2007). 
51. Brásio (MMA-I, v. 1, doc. 65 , p. 240). Para um resumo da literatura disponível, ver especialmente a nota 1 do texto.

52. Regimento de D. Manoel a Manuel Pacheco e Baltasar de Castro (1520). Brásio (MMA-I, v. 1, doc. 128, p. 436).

53. Regimento de D. Manoel a Manuel Pacheco e Baltasar de Castro (1520). Brásio (MMA-I, v. 1, doc. 128, p. 437)

54. Em 1445 foi criada em Lagos (Portugal) a Casa da Guiné, transferida para Lisboa em 1463, quando foi instalada no Paço da Ribeira. Daí em diante mudou de nome para Guiné e Mina, depois Guiné, Mina e Índia. Em 1503 foi criada a Casa da Índia e o controle das alfândegas das possessões africanas e asiáticas foi separado.

55. Brásio (MMA-I, v. 1 doc. 218 , p. 436, 437).
Silva investigar como se faz o comércio no Congo. Dada a experiência de comércio no ultramar, os portugueses estão atentos à existência de diferentes alternativas de comércio. Em alguns lugares se negocia com comerciantes estabelecidos, em outros com autoridades políticas locais. É com esse espírito que D. Manoel determina:

Vós trabalhareis de saber do trato que lá pode haver e de que coisas e de cuja mão se puderam haver e se os escravos e cobre e marfim e as outras mercadorias que na terra houver se hão todas da mão do Rei, ou se há aí mercadores. ${ }^{51}$

Em 1520, D. Manoel passa outro regimento que instrui Manuel Pacheco e Baltasar de Castro em sua viagem a Angola. Nos mesmos moldes do anterior, esse regimento estabelece regras para os carregamentos, só que são referentes a Angola: "carregando-os o dito rei de Angola o navio de escravos e marfim ou metais, parece-nos que não deveis passar por diante e que deveis de vos tornar com a dita carga dar-nos conta do que achais". 52 Ou seja, as mercadorias arrecadas não deviam ser repassadas por comerciantes e sim enviadas diretamente a São Tomé. Não fica claro se é um carregamento de comércio ou compensação. Esse regimento trata das carregações de cobre e marfim em separado das de escravos:

Vireis com a vossa armação à dita llha de São Tomé, onde entregareis toda a armação ao nosso feitor... E assim the entregareis por conto e peso os metais e marfim que trouxerdes. E tanto que tiverdes posto o navio a monte, se lhe for necessário e reparado do que the cumprir para nele virdes ao Reino, tornareis a recolher os ditos metais e marfim ... e mais a carga dos escravos vós o feitor e oficiais derem, posto que não sejam os próprios que resgatastes e vós vireis via do Reino entregar à nossa Casa da Mina, e daí vós vireis a nós dar-nos conta do que fizestes. ${ }^{53}$

Esse trecho indica que Manuel Pacheco e Baltasar de Castro não são os únicos a resgatar. Também entram nesse comércio o feitor e oficiais. Ao contrário do regimento passado para o Congo em 1512, não há, neste, qualquer referência explícita à compensação. Apenas a não menção declarada a resgate nas carregações de metais e marfim. Por outro lado, nada comprova a ausência de compensações em Angola. $\bigcirc$ trecho indica ainda o caminho a ser seguido pelo carregamento: de São Tomé a embarcação vai diretamente à Casa da Mina, em Lisboa. ${ }^{54} \mathrm{Em}$ resumo, o regimento de 1521 indica claramente que, sem excluir possíveis presentes e compensações, o espírito comercial presidia as negociações em Angola. Talvez por isso acrescente a recomendação de investigar a região sobre ouro, prata, outros metais e marfim; e instrua Manuel Pacheco e Baltasar de Castro na arte de comerciar, alertando que "enquanto a coisa valer mais, e cá for mais estimada, tanto menos the dareis a entender que a estimais para não encarecer". ${ }^{55}$

Embora não tenha sido feita uma quantificação das remessas de marfim no século XV, a leitura da documentação aponta para uma 
concentração do comércio de marfim nos portos dos chamados "rios de escravos" e no Congo, cabendo ao Congo ainda o marfim da compensação, e muito pouco marfim de Angola. A entrada em Portugal de marfim, assim como de todas as outras carregações do ultramar, poderia ser atestada nos registros da alfândega de Lisboa, mencionados pelos regimentos. Para o século XVI foram encontrados apenas registros de 1504 e 1505. Neles Peter Mark encontrou referência a colheres e saleiros de marfim. Esses registros parecem ser os únicos disponíveis. $\bigcirc$ restante da série, como alerta Mark, pode ter-se perdido por ocasião do terremoto de Lisboa, em 1755.56 desaparecimento dos registros de entrada de mercadorias em Lisboa dificulta o cálculo do volume de marfim envolvido nessas transações, mas a importância a ele atribuída na documentação administrativa aponta para um volume substancial para os padrões da época.

controle exercido pelo feitor de São Tomé sobre os carregamentos se aplica a toda extensão da capitania, o que the dava grande poder de barganha junto aos armadores e capitães, tanto dos navios que vinham de Portugal, quanto das embarcações locais. Não à toa, já em 1499 Pedro Álvares de Caminha queria garantir para si a herança de seu falecido tio. ${ }^{57}$ Importante lembrar que já nas primeiras décadas do século XVI outras nações europeias começam a percorrer a costa e que há registros de que aportam em São Tomé, para compra de suprimentos (tolerada) e comércio de marfim (proibido).

Faltam também números para o comércio nos rios dos escravos, mas a documentação permite concluir que havia um comércio regular a partir das primeiras décadas do século XVI. Uma carta dos feitores da Casa da Mina (26 set. 1523) trata do comércio de Cabo Verde e rios de Guiné lque inclui o marfim vindo de Serra Leoa), indicando uma baixa no comércio de marfim e um crescente rendimento no comércio de escravos (peças):

Deveis trabalhar daqui em diante de tirardes peças dos rios, porque segundo a pouca valia do marfim, é melhor fazerdes peças. Portanto fareis por tirardes dos rios este ano todas as peças que poderdes. E também algum marfim, mas no resgate dele se tenha temperança porque não tem nenhuma valia. ${ }^{58}$

$\bigcirc$ desinteresse de Portugal pelo marfim foi, portanto, proporcional ao rápido crescimento do comércio de escravos, abrindo assim espaço para que outras nações europeias não envolvidas no comércio de escravos tivessem acesso mais fácil ao marfim que, a essa altura, tinha demanda na Europa, mas, como diz o feitor, não valia nada se comparado aos escravos. Essa mudança de prioridades e a rapidez com que os franceses ocupam o lugar deixado pelos portugueses ficam evidentes na carta do Mani Congo Nzinga Mbemba, datada de 1526. Ele informa ao rei de Portugal estar tendo dificuldades para mandar o marfim da compensação pelas despesas da Coroa portuguesa com seus "fidalgos" residentes em Portugal. $\bigcirc$ motivo seria a recusa dos pilotos de fazerem seu transporte:
56. Mark (2007, p. 195).

57. Seus planos fracassaram. Ainda em 1499 o capitão donatário nomeado para suceder Álvaro de Caminha foi Fernão de Melo. Marques (1984, p. 461464, v. II).

58. "Carta dos feitores da Casa da Mina” (1523). Brásio (MMA-II, v. 2, doc. 60, p. 185). 
59. Brásio (MMA-I, v. 1, doc. 145 , p. 484).

60. Brásio (MMA-I, v. 1, doc. 144 , p. 476).

61. Brásio (MMA-I, v. 2, doc. 7 , p. 369).

62. Martin (1972, p. 17). No Brasil, os escravos vindos dessa região são chamados "angicos". Em grande parte da literatura acadêmica mundial são conhecidos como Teke ou Tyo/Tio. Esse território, assim como o reino do Loango, foi incorporado ao Congo francês em 1882. Sobre os Tio no século XIX, ver Vansina (1973).

63. Segundo Hilton, ao contrário de seus antecessores, nas últimas décadas do século XVI o Mani Congo possuía uma guarda de 16 a 20 mil escravos Tio em Mbanza Kongo (capital do Kongo) e outras localidades estratégicas. Hilton (1985, p. 85).

64. Objetos de cobre eram uma das principais riquezas dos povos da savana e braceletes e colares de cobre estavam entre os objetos de luxo mais desejados. Do interior vinham ainda rabos de elefante com os quais se faziam braceletes e outros pequenos objetos tecidos ou enrolados. $\mathrm{O}$ marfim era usado como objeto ornamental e como instrumento musical. Ver Martin (1972, p. 53-135) e Herbert (1984).
Senhor, nós temos muito marfim e cada dia nos vem, o qual desejamos mandar em vossos navios a esses reinos para com ele escusarmos as despesas que $V$. A. com nossas coisas faz e os vossos pilotos no-lo não querem levar. ${ }^{59}$

A recusa dos pilotos muito provavelmente tem a ver com o fato de que o marfim da compensação ocupa espaço nos porões dos navios e seus pilotos e armadores nada recebem por seu transporte. Mas essas recusas, em alguma medida, refletem também os interesses da Casa da Mina. A partir da década de 1520 cresce o comércio de escravos devido à demanda de escravos na América Espanhola, e a partir de meados do século também no Brasil. Esse parece ser também o momento de mudança nas informações hoje disponíveis sobre os objetos feitos de marfim.

Não foi difícil para os franceses que já estavam na Costa da Mina descer à foz do Zaire, para tentar acesso ao marfim. Embora o ouro fosse o maior atrativo, o marfim tinha mercado e ainda servia de lastro para as embarcações nas viagens de retorno à Europa. Confirmando essa argumentação, na mesma carta de 1526 Nzinga Mbemba informa a D. João III de Portugal sobre a chegada de franceses a Pinda para negociar marfim, manilhas (argolas de cobre) e tacula (pauvermelho) com o Conde do Sonho. ${ }^{60}$ Bem poderiam os franceses da Normandia que navegavam por terras portuguesas terem chegado ao Congo e ali comprado pelo menos parte dos 100 quintais de marfim que, como dito acima, foram desembarcados em Roven em 1531.

Em 1532, alegando que o Mani Congo Nzinga Mbemba prometia atender a toda a demanda portuguesa (em troca da exclusividade do comércio), o regimento do feitor de São Tomé ordena o fechamento do comércio com Angola, em benefício do Congo. ${ }^{61}$ A documentação portuguesa se refere a essa vasta região interiorana como Anzicana, uma área habitada por diferentes povos governados pelo grande Angeca. ${ }^{62}$ Não é à toa, portanto, que são sempre tensas as relações entre o Loango e o Congo. De ex-tributário no século XVI, o Loango passa a concorrente do Congo e a fornecedor de marfim vindo da Anzicana em troca de panos de ráfia e sal junto aos portugueses. Outra parte do estoque de marfim português continuava a ser negociada pelo Congo. Já então os comerciantes do Congo iam ao interior em busca de escravos para venda e para seu uso. ${ }^{63}$ Acresça-se a isso o fato de que até o século XVII os chamados Anzicos controlam as minas de cobre do Mindouli que era parte do Bukkameale. Com ele os Vili acrescem ao seu comércio uma cobiçada mercadoria também oferecida a seus parceiros europeus, ao lado do marfim. ${ }^{64}$

A presença de portugueses, franceses, holandeses e ingleses ao longo da costa leva à criação de circuitos comerciais concorrentes que envolvem diferentes mercadorias e portos ao longo da costa. Essa nova demanda leva também a uma reorganização dos circuitos comerciais nos portos atlânticos da costa africana e no interior, alterando as rotas das caravanas e as mercadorias por elas negociadas. Anne Hilton descreve a rota do cobre entre o Mindouli e o 
Congo. Segundo ela, o Mani Congo Nzinga-a-Nkuwu, que governa o Congo por ocasião da chegada dos portugueses (batizado D. João I), tinha apenas marfim e panos de ráfia para oferecer ao rei de Portugal. Já seu sucessor, Mvemba-a-Nzinga (batizado Afonso I), que governa de 1509 a 1540, passa a oferecer manilhas de cobre vindas do Mindouli. ${ }^{65}$

Enquanto o porto de Pinda entra no circuito português do marfim ainda no século XV, o porto do Loango só passa a ser mencionado no final do século XVI. Certamente o porto já integrava os circuitos (panos, de ráfia, sal), mas a partir de então cresce a demanda por marfim e tacula. Cresce também a demanda por sal e panos usados como meio de troca nas caravanas que saem do Loango para negociar no interior. Entre as mercadorias negociadas nessas rotas comerciais havia ainda cobre (geralmente manilhas), tacula e xingos (pelos do rabo do elefante), além de outros produtos de menor importância. ${ }^{66}$ A maioria dos produtos era usada para consumo local ou troca intermediária para facilitar a aquisição do marfim e do cobre. Feito esse comércio, a carregação é enviada a São Tomé no caso dos portugueses, ou diretamente à Europa no caso dos franceses, e depois dos holandeses.

Existem poucas informações sobre as primeiras explorações da costa do Loango. Em 1481 Diogo Cão deu à praia o nome de Praia Formosa de Santo Domingo. ${ }^{67}$ Desde então, é possível que exploradores e armadores de São Tomé tenham feito paradas na região. Não há, entretanto, qualquer indicação da presença de portugueses no Loango antes de meados do século XVI. Nessa ocasião, por recomendação do rei do Congo, o missionário Sebastião de Souto vai ao Loango. Entre outros feitos, seu relato narra a conversão do "rei" do Loango e de um de seus irmãos ("sacerdote de Quilembo") à fé cristã, com a subsequente destruição de "ídolos e feitiços". ${ }^{68}$ No século XVI, as relações do Loango com o Congo - de quem o Loango teria sido tributário no passado - eram tensas, e a atitude do Mani Loango (ou Maloango) pode ter sido uma tentativa de retomar sua influência sobre o território perdido. ${ }^{69}$ Por essa e outras escassas informações sabese que, em meados do XVI, o Loango era um território estabelecido sobre o qual governava uma autoridade centralizada que regulava as condições de comércio com os estrangeiros. ${ }^{70}$ Voltando à preocupação manifestada por D. Manoel sobre quem fazia o comércio em cada porto, é possível dizer que o Maloango centralizava o comércio, tornando mais difícil que no Congo o acesso dos portugueses aos comerciantes locais. ${ }^{71}$

Segundo Jan Vansina, por volta da década de 1580 caravanas vindas do Loango já iam ao interior comprar marfim e panos de ráfia em troca do sal produzido no litoral. ${ }^{72}$ Assim, o comércio com o interior e o aumento da demanda de marfim e cobre no Atlântico estão associados à expansão da rede comercial do reino do Loango e ao crescimento poder do Maloango em relação a outras chefias da margem direita do Zaire. $O$ crescimento da presença europeia ao longo do século XVI foi determinante para o Loango que, se não surge, claramente se beneficia da nova configuração comercial, assumindo uma posição de
65. Hilton (1985, p. 54-55).

66. Martin (1972, cap. 2).

67. Martin (1972, p. 33).

68. Apontamentos de Sebastião de Souto (1561). Brásio ( $M M A-I$, v. 2, doc. 167). O "rei do Congo" nessa ocasião era D. Diogo (Nkumbi a Mpudi), que governou entre 1545-1561.

69. Segundo Martin, pelo menos desde a década de 1530 o Congo já teria perdido até mesmo o controle nominal sobre o Loango. Martin (1972, p. 9).

70. Segundo Samuel Brun, que ali esteve em 1611, o Maloango reinava sobre seis "reis". Jones (1983, p. 50).

71. Martin (1972, p. 34).

72. Vansina (1962, p. 378). Posteriormente, em Paths in the Rain Forests, o autor apresenta um mapa com a distribuição dos produtos e de oficinas para tecelagem de panos, metalurgia, construção de barcos e também salinas. Vansina (1990, p. 212-214). 
73. Brásio $(M M A-1$, v. 2, doc. 116, p. 467). predominância na margem direita do Zaire em decorrência do comércio do marfim, quase um século antes de se tornar um porto de comércio de escravos. A solidez das redes comerciais do Loango com o comércio de mercadorias permitiu a seus comerciantes e autoridades políticas negar exclusividade a qualquer parceiro comercial, fossem eles locais ou europeus.

Os chamados caçadores de Bukkameale (possivelmente o Vale do Niari, situado no sudeste da atual República do Congo) trocavam marfim pelo sal trazido do litoral pelas caravanas do Loango. Esse e outros circuitos comerciais entre o interior e o litoral mostram que o Loango já tinha no início do século XVI uma rede comercial que se ampliou ao longo do século. A eficiência dessa organização se devia, provavelmente, à centralização do comércio pelo Maloango e seus representantes e agentes, os chamados Vili, conhecidos comerciantes do Loango. Em contrapartida, o Loango era pobre em ferro, produto que passa a comprar dos portugueses e depois dos holandeses. Assim, ao longo do século XVI os Vili intermediam o comércio dos portugueses com o interior la chamada Anzicana), uma função que cabia ao Congo.

A tensão resultante da concorrência entre os comerciantes da capitania de São Tomé (Benim, Congo e Angola) se prolonga até 1587, quando o contrato de Angola é separado do contrato de São Tomé. Essa mudança é contemporânea à entrada do Loango no comércio de marfim e da predominância de Angola no comércio de escravos. Naquele ano Pedro de Sevilla e António Mendes de Lamego assinam o contrato de Angola: uma terça parte dos escravos adquiridos devia ser enviada às Índias de Castela; tinham ainda preferência na retirada de todos os metais descobertos (cobre) e por descobrir (prata e ouro), pelo prazo de seis anos. $\bigcirc$ contrato estabelece ainda que todo o marfim resgatado deveria ser embarcado para Lisboa, sem pagamento de direitos à Fazenda Real. Antes de ser embarcado, devia ser levado à Casa da Feitoria do Reino de Angola para ser "visto e pesado", como era feito anteriormente em São Tomé. Continua também a ser responsabilidade dos contratadores fazer seguir, junto com o carregamento, o certificado emitido pela feitoria, onde se declara a "quantidade" e o "peso" do marfim despachado. ${ }^{73}$

Paralelamente ao comércio de escravos no rio Benim (feitoria de Santo António, em São Tomé) e na costa do Loango, Congo e Angola (feitoria de Luanda, em Angola), os comerciantes portugueses continuam a comprar marfim, cobre e outras mercadorias. A produção de marfim de Angola nunca foi grande e suas exportações vinham do Congo e do Loango. Com as frequentes guerras, as exportações de marfim do Congo diminuem e o comércio da Anzicana se volta para o Loango. A separação da costa em duas feitorias (São Tomé e Luanda) facilita o comércio de escravos (concentrado em Angola), mas faz surgir um problema para o comércio do marfim (disperso na costa). Antes todo o marfim vindo do rio Benim, Loango e Congo era reunido em São Tomé. Por ocasião da divisão das feitorias, ficou difícil controlar as rotas do marfim, já que o crescente comércio dos portos ao norte do Zaire, especialmente o Loango, era de difícil controle para 
a feitoria de Luanda. Com a eficiência de sua rede comercial e a dificuldade dos portugueses em controlar o comércio ao norte do Zaire, rapidamente o Loango se torna um centro de comércio independente.

Essa preponderância do Loango aparece nas narrativas de Andrew Battell e Duarte Lopes, que negociam marfim do Loango no final do século XVI. Viajar ida e volta Luanda-Loango enfrentando a adversidade dos ventos da costa tornava esse comércio caro e arriscado. A isso se acrescia a resistência do Maloango em permitir o estabelecimento de uma feitoria/um forte português/ portuguesa em suas terras. Diante dessa adversa conjuntura comercial, os portugueses optam pela construção de um forte em Pinda, com a concordância do Mani Congo, mas não do Mani Sonho. Para o Mani Congo a presença portuguesa em Pinda limitaria as pretensões do vizinho e seu conhecido comércio com franceses e holandeses. Perder o comércio de marfim do Loango é o preço pago pelos portugueses para manter o controle sobre a foz do Zaire e o comércio de Pinda. Já então eram os escravos e não o marfim que estavam em jogo.

Como alternativa ao comércio do Loango e Congo, a partir de meados do século XVI cresce o interesse pelo comércio de Angola ao sul de Luanda. Mariana Candido aponta Benguela como alternativa ao atribulado comércio com o Congo. Paulo Dias Novais, explorador e primeiro capitão de Angola, chega à ilha de Luanda em 1575, onde estabelece o primeiro povoado. Em 1576 funda a vila de São Paulo de Luanda e governa Angola até 1594.74 Nessa ocasião, já por um século, os portugueses circulavam pela foz do rio Zaire comerciando marfim e outros produtos; também ali já estavam desde 1526 os franceses e mais tarde, os holandeses. O Catálogo dos governadores de Angola mostra essa estratégia e narra o início dos resgates ao sul de Luanda, por ocasião da chegada de Novais: "principiaram a estender o negócio pela costa do sul, mandando a ela vários patachos e outras embarcações a resgatar escravos, marfim, cobre, gados e mantimentos". ${ }^{75}$ Em resumo, ao norte, melhor que enfrentar a resistência do rei do Loango era tentar um acordo com o rei do Congo. Ao sul, como alternativa ao Loango perdido, foi ampliada a presença portuguesa no litoral para acesso às rotas comerciais do planalto. Já em 1546 os portugueses dão notícias de um "reino" de Benguela com muitos reis e senhores gentios. Em 1587 foi lá estabelecido o primeiro porto marítimo ao sul do Cuanza, logo depois abandonado (mais tarde conhecido como Benguela Velha ou Porto Amboim); e em 1617 foi finalmente construído o forte de São Felipe e fundada a vila de São Felipe de Benguela, na Baía das Vacas. ${ }^{76}$

A virada do século XVI para o XVII foi, portanto, crucial para o estabelecimento territorial português e a montagem da engrenagem do comércio atlântico de escravos, mas também para a organização do circuito comercial de marfim. ${ }^{77}$ Importante lembrar que, nesse contexto, o Loango e o marfim deixam de ser prioridade para os portugueses, mas continuam na mira de outras nações europeias.
74. Academia (1825, p. 349).

75. Elaborado a partir da História geral das guerras angolanas, de António de Oliveira Cadornega (1680), o catálogo é uma fonte controversa. Ver Miller; Thornton (1987).

76. Candido (2013, p. 31-50).

77. Para uma nova abordagem do comércio atlântico de escravos e outras mercadorias, ver Schultz (2016). 
78. A monografia considerada clássica sobre o Loango é a já citada obra de Martin (1972) Há ainda um trabalho em francês ao qual não tive acesso: HAGENBUCHER-SACRIPANTI, Frank. Les Fondements Spirituels du Pouvoir Au Royaume de Loango, Rèpublique Populaire du Congo. Paris: O.R.S.T.O.M., 1973. Jan Vansina trata do tema em suas diferentes abordagens da região, em especial em $\mathrm{Pa}$ ths in the Rainforests.

79. Ravenstein (1901, p. 9 , 15, 47 e 86).

80. Carta ânua da missão de Angola, 1603. Brásio (MMA$-I$, v. 5 , doc. 30 , p. 82-83). Manoel Cerveira Pereira foi governador de Angola por duas vezes: 1603-1606 e 1615-1617. No segundo governo construiu o forte de São Felipe de Benguela, onde sediou a capital do novo Reino de Benguela que existiu entre $1616 \mathrm{e}$ 1869. O capítulo 19 do regimento de Manuel Cerveira Pereira para a conquista de Benguela (12/3/1615) menciona o resgate de marfim. Benguela tinha mais marfim que Angola.

81. Um episódio narrado pelo comerciante holandês Pieter van den Broecke, durante sua permanência no Loango, exemplifica essa tensão. Holandeses e portugueses teriam se enfrentado a ponto de serem feitos prisioneiros e um português ser golpeado com uma "presa de elefante". Como não há qualquer referência a armas de marfim, é provável que esses homens tenham usado o próprio lote de presas ali disponível para o ataque. La Fleur (2000, p. 54-55).

82. A edição inglesa de 2000 teve o relato transcrito e editado por La Fleur, que acrescentou um prefácio, uma introdução e uma nota contextualizando o manuscrito, com rigorosa crítica do documento e comentá-
A entrada do marfim do Loango no comércio colonial

As fontes históricas e arqueológicas até agora analisadas não dão muitas pistas sobre o surgimento de Loango como uma unidade política centralizada na figura do Maloango. Por ocasião da chegada dos portugueses à costa, o Maloango teria se rebelado recentemente contra o domínio do Mani Congo, cujos poderes então se estendiam à margem direita do rio Zaire. ${ }^{78}$ Por volta de 1590, durante sua permanência forçada em Angola, o inglês Andrew Battell visitou o Loango e ali fez negócios a mando do governador de Angola. No capítulo "Trading in Loango" registra ter negociado um yard (0,92 mt) de tecido por três dentes de elefante de 120 libras; muito pano de ráfia e rabos de elefante. Se refere também às trombetas de marfim (chamadas pongo ou mpunga) que descreve como um instrumento feito com dente de elefante, oco por dentro, medindo um yard e meio, com uma abertura como a de uma flauta, emitindo um som alto e áspero que podia ser ouvido a uma milha de distância. ${ }^{79}$

A primeira referência ao Maloango na documentação portuguesa é sua aparente bem-sucedida conversão, por ocasião da já citada visita do missionário Sebastião de Souto em cerca de 1561. Depois disso, uma carta ânua da Missão jesuíta de Angola, datada de 1603, informa sobre um suposto pedido do Maloango para que os padres da Companhia levassem a catequese a seu povo, numa segunda tentativa de conversão. Segundo a carta, já então alguns "moços fidalgos" do Loango estariam aprendendo a doutrina com o "feitor do contrato" que ali residia e que é descrito como "grande amigo" dos jesuítas. A existência de um feitor residente indica a presença portuguesa e um comércio minimamente organizado. A carta informa ainda que estaria no Loango naquela ocasião um padre da Companhia de nome Jorge Pereira. A carta faz também referência ao governador de Angola, Manoel Cerveira Pereira, alegando ser o mesmo "devotíssimo da Companhia". ${ }^{80}$ Vê-se então que o contratador continuava a atuar no Loango através de seu feitor e que ambos tinham boas relações tanto com os jesuítas quanto com o governador.

A ida de um feitor e de missionários jesuítas para o Loango é, quase certamente, um esforço para evitar a perda completa daquele porto. Apesar da prioridade dada pela Coroa portuguesa a Angola, os personagens locais da história tinham seus próprios planos e nunca abandonaram completamente o Loango. Os jesuítas não convertem o reino ao catolicismo, mas todos os personagens que atuaram nesse episódio conviveram, como puderam, com os holandeses que já por ali andavam, ao que dizem, com a simpatia do Maloango ${ }^{81}$ Entre 1599 e 1608 os holandeses enviam cerca de 200 embarcações a África. Nesse período o comércio holandês era feito através de pequenas companhias que percorriam a costa, ainda sem condições de competir com os portugueses, mas visando ao ouro da Mina e ao marfim do Loango. $O$ único registro detalhado da presença de comerciantes de marfim no Loango foi deixado pelo já mencionado Pieter van den Broecke (nasc. 1585-fal. 1640). ${ }^{82}$ Seu precioso relato mostra em 
detalhes como os comerciantes holandeses negociavam, oferecendo aos comerciantes locais tecidos e outras mercadorias de melhor qualidade que a oferecida pelos portugueses, além de pagamento imediato, ou a curto prazo. $\bigcirc$ relato de Van den Broeck tem sido pouco explorado pela historiografia. ${ }^{83}$

Como demonstra Van den Broecke através de suas contas, ele, e provavelmente outros comerciantes holandeses, tinha a seu favor o fato de negociar mercadorias mais baratas e de fácil estocagem que os escravos: tacula, panos de ráfia e marfim. ${ }^{84}$ Os dois primeiros eram usados principalmente em transações intermediárias, sendo a compra do marfim o objetivo final da viagem. A tacula, testada para tingimento de tecidos, era levada para Amsterdã, mas nunca se constituiu no principal objetivo das viagens. Esse padrão de negócio caracteriza as firmas comerciais holandesas anteriores à fundação da WIC (West-Indische Compagnie). A partir da WIC, criada em 1621, e da ocupação do nordeste do Brasil, os holandeses entram no comércio de escravos. ${ }^{85}$

$\bigcirc$ diário de viagem de Van den Broecke mostra como o comércio do marfim desempenha papel preponderante em seus negócios. Van den Broecke faz quatro viagens à costa atlântica africana: na primeira vai a Cabo Verde, Guiné (Senegâmbia) e Angola (na verdade Loango) e de lá às Índias Ocidentais (16051606); nas outras três vai diretamente ao Loango, retornando de lá a Amsterdã, em 1609-1611; e 1611-1612. Pela leitura de seu relato é possível perceber que a estratégia era fazer os negócios que se apresentavam, comprando e vendendo todo tipo de mercadoria para revender mais adiante, e chegar ao maior número de dentes de marfim a serem levados para Amsterdã. Embora Van den Broecke faça referência à compra de algum marfim na Senegâmbia, vou me concentrar em suas informações sobre o marfim do Loango, de onde sai a maior parte de suas carregações. Seu comércio se concentra nos portos do Loango e Maiomba lao norte do Loango), onde teria aberto feitorias em 1610 e 1612, respectivamente. ${ }^{86}$ Do Loango seu navio e as demais embarcações da pequena companhia se deslocavam para outros portos, inclusive Pinda, para depois voltar e armazenar as compras no Loango, até a hora do retorno. ${ }^{87}$

$\bigcirc$ conjunto dos três relatos indica uma regularidade nas viagens. A companhia para a qual van den Broecke trabalhava tinha sede em Amsterdã. Seus navios eram carregados e descarregados naquela cidade. Como não se sabe o nome da companhia, só é possível identificar as viagens registradas por Van den Broecke, entre 1605 e $1612 .{ }^{88} \mathrm{Na}$ saída de Amsterdã, embarcações faziam uma parada em Texel. Na costa do Loango os vários navios da companhia negociavam suas mercadorias em separado, mas de modo coordenado, auxiliados por barcas e outras embarcações menores. Conforme os navios eram abastecidos eram enviados de volta. No retorno faziam também parada em Texel e de lá seguiam para Amsterdã, onde eram descarregados, e se faziam os acertos da viagem. ${ }^{89}$

Na primeira viagem, Van den Broecke embarca como feitor júnior do navio Neptunnis, que partiu de Amsterdã, fez uma parada em Texel e tomou o rumo da África em novembro de 1607, chegando à baía do Loango em abril de 1608. rios em notas ao longo do texto. La Fleur (2000, p. xiii-xv; 1-17; 18-22).

83. Conforme as respectivas bibliografias, Martin cita a edição holandesa de 1950 e Sommerdyk, a inglesa de 2000, a mesma aqui citada. Martin (1972, p. 181); Sommerdyk (2012, p. 252).

84. La Fleur (2000, p. 1-17). Ao tratar do comércio do Congo, Anne Hilton argumenta na mesma direção. Hilton (1985, p. 116).

85. Sobre as conexões entre o Loango e o Brasil, a literatura é especialmente escassa. A tese de Roquinaldo Ferreira (2003) dá grande destaque ao comércio no porto do Loango e suas conexões com o Brasil a partir de 1650. Sommerdyk (2012) recua em sua análise para a primeira metade do século, concentrando sua atenção na WIC e, portanto, nas remessas de escravos para o Nordeste do Brasil. Martin (1972) se concentra no século XVIII. Os capítulos 1 e 2 são ainda o resumo mais completo disponível sobre o Loango, mas ignoram as conexões com o Brasil. Alencastro apenas inclui o Loango no mapa das rotas transatlânticas, com raras referencias, a primeira de 1637. Alencastro (2000, p. 62 e 251; referência p. 212/ nota 216). Mesmo Boxer, em seu clássico Salvador de Sá e a luta pelo Brasil e Angola, praticamente ignora o Loango, registrando apenas que, ao tentar sair de Luanda em 1650, Salvador de Sá informa ao rei que o comércio vai bem e que o Loango parece mais disposto a negociar com os portugueses que com os holandeses, notícia facilmente discutível. Boxer (1973, p. 298).

86. O diário de Van den Broecke faz várias referências ao comércio do marfim e de outras mercadorias. Não há menção ao comércio de escravos. No fim do 
diário, um texto intitulado "Description of the Kingdom of Loango" foi acrescido ao manuscrito. Os alertas de La Fleur sobre a escrita do diário foram levados em consideração e não afetam as informações aqui citadas de modo a comprometer seu conteúdo. Sobre o texto do Loango, ver La Fleur (2000, p. 15).

87. O extenso debate sobre a construção de uma fortaleza em Pinda na verdade resulta da desistência portuguesa de controlar o comércio no Loango e sua tentativa de ao menos garantir acesso exclusivo a Pinda, evitando assim o acesso dos holandeses e franceses ao reino do Congo.

88. Ver explicação sobre a chamadas "pré-companhias" que foram anteriores à VOC e WIC. La Fleur (2000, p. 4); ver também nota 2, em que La Fleur resume as primeiras viagens holandesas ao Congo no final do século XVI. La Fleur (2000, p. 54).

89. Texel é uma pequena ilha holandesa do Mar do Norte onde ficava um posto de controle, última parada antes do Atlântico. O TSTDB registra Texel como destino final das viagens holandesas. O relato de Van den Broecke mostra que depois da parada em Texel os navios seguiam viagem para desembarcar suas mercadorias em Amsterdã.

90. Primeira viagem a Angola como feitor assistente a bordo do Neptunnis sob o comando do mercador Harman Bitter. La Fleur (2000, p. 43-67).

91. Segunda viagem a Angola como feitor principal a bordo do Mauritius. La Fleur (2000, p. 69-81).

92. Terceira viagem a Angola como feitor chefe a bordo do Son (Neptunnis reno-
Uma vez instalado, Van den Broecke registra seu comércio. Em maio de 1608, logo depois de chegar, faz sua primeira compra: 14 presas de elefante (200 libras $=3.000$ réis) pagas com 11 ells de vierlooden vermelho. Segundo La Fleur, eram presas pequenas e de segunda classe (média de 14,3 libras holandesas = 4,29 $\mathrm{kg}=15.71$ libras inglesas). Mais adiante informa que, ao deixar o Loango em outubro do mesmo ano, tinha comerciado 1.788 peças de presas de elefante pesando 37,21 3 libras holandesas. Do Loango volta a Texel, onde chega em 4 de junho de 1609, indo dali para Amsterdã. $O$ Neptunnis levou cinco meses e meio de Texel ao Loango (de 14 de novembro a final de abril); e depois sete meses do Loango a Texel (do final de outubro a 4 de junho de 1609). ${ }^{90}$

A segunda viagem foi feita na condição de feitor principal. A embarcação Mauritius sai de Amsterdã e faz parada em Texel, de onde parte em 17 de setembro de 1609. Antes de chegar ao Loango para em Maiomba, onde faz duas compras: uma em unidades (quatro presas pesando 74 libras); e outra por peso (361 libras, a 4 mil-réis o quintal). Chega ao Loango no dia seguinte, 30 de janeiro. Em 14 de fevereiro carrega seu navio com 785 libras de marfim e vai para o Congo. Em 19 de março compra 15 quintais de marfim a 4 mil-réis por quintal. ${ }^{91}$

Na terceira viagem parte de Amsterdã em outubro de 1611 e chega ao Loango em 23 de fevereiro de 1612. Ao chegar encontra 62 mil libras de marfim estocadas, compradas pela barca que deixara encarregada de continuar o comércio até sua volta. No dia 23 de março manda a barca para o rio Benim, rios do Gabão e baía do Corisco e um navio para o Congo. Essa compra mostra como a divisão das feitorias complica a vida dos portugueses envolvidos no mesmo comércio e favorece o descaminho e o subregistro. Deixa o Loango em junho com 35 presas de elefante, pesando 1.905 libras. Em 17 de setembro o navio chega a Amsterdã com 96 mil libras de marfim e outras mercadorias, dando grande satisfação à direção da Companhia. ${ }^{92}$

A esses carregamentos somam-se ainda alguns lotes mencionados ao longo dos relatos. Na primeira viagem, além do carregamento do Loango, Van den Broecke compra um lote de marfim em Olibate (próximo ao Cabo Lopes). $\mathrm{Na}$ segunda viagem outros dois navios aparentemente da mesma companhia embarcam marfim: Van der Voordt leva 63.000 libras de marfim; e Pieter Brandt 50 mil libras. Na terceira viagem, uma pequena embarcação sob seu comando, de passagem pela Grain Coast, compra 300 libras de marfim. ${ }^{93}$ Assim como acontecera nos primeiros contatos dos portugueses com o Mani Congo, Van den Broecke também recebe presentes. Talvez o mais valioso deles tenha vindo da "irmã" do Maloango que, segundo ele, teria tentado seduzi-lo. Entre outros mimos ela teria enviado um dente de elefante de 90 libras (cerca de 45 quilos), a metade do tamanho do dente oferecido por Cadamosto a D. Henrique. Do próprio rei recebe vários outros presentes, entre eles três lotes de marfim: o primeiro com 16 presas (mil libras, 62,5 libras cada); o segundo com duas presas (1 80 libras, 90 libras cada); e o terceiro com 35 presas (1.905 libras, 
54,4 libras cada). No dia 13 de abril inicia a viagem de volta. $\bigcirc$ navio chega a Amsterdã dia 27 de julho com um carregamento de 1.800 peças de tacula; e pelo menos 65 mil libras de marfim compradas no Loango, Kakongo, Sonho, Maiomba e Cascais. ${ }^{94}$ Apesar do sucesso comercial da viagem, dos presentes e convites, não retorna mais ao Loango. ${ }^{95}$

Um cálculo aproximado do comércio de $v$ Van den Broecke e dois de seus parceiros pode ser obtido a partir das informações de suas viagens da companhia, entre 1608 e 1612 :

\begin{tabular}{|c|c|}
\hline COMERCIANTES & VALORES \\
\hline Van den Broecke/1 & 37.000 libras (p. 61) \\
\hline Van den Broecke/2 & 65.000 libras (p. 80) \\
\hline Van den Broecke/3 & 96.000 libras (p. 93) \\
\hline Van der Voordt & 63.000 libras (p. 74) \\
\hline Pieter Brandt & 50.000 libras (p. 88) \\
\hline TOTAL & 311.000 libras de marfim \\
\hline
\end{tabular}

Esse número representa um total de 10.367 presas pequenas 15.183 elefantes) a 30 libras cada; ou 5.183 presas médias (2.591 elefantes), a 60 libras cada; ou 3.455 presas grandes (1.727 elefantes), a 90 libras cada. Como os carregamentos anotados cobrem cerca de cinco anos, é possível estimar a morte de cerca de 500 elefantes por ano para atender à demanda de uma companhia. ${ }^{96}$

O diário de Van den Broecke não menciona paradas na Costa da Mina na viagem de volta. Como a intenção dessa parada seria o ouro, ela pode ter sido omitida; ou pode também ocorrer de a companhia dedicar-se apenas ao comércio de mercadorias. Não era, entretanto, esse o padrão das viagens holandesas. Um episódio ocorrido na Capitania do Maranhão informa sobre uma embarcação holandesa perdida no litoral do Ceará vinda da Mina com carregamento de ouro. O episódio teria acontecido em 1612, quando Martim Soares, capitão do Ceará, tomou o dito navio holandês na barra do rio Ceará:

[...] tomou o dito Martim Soares um navio holandês com ajuda dos Índios, indo ele nu entre eles, e tingido de jenipapo, que faz a carne como negro de Guiné; matando em terra, e no dito navio 42 homens fiando senhores da nau, e do que tinha em si de mantimentos, armas, e artilharia, e munições, e com este sucesso aumentando-se o crédito da dita povoação, fizeram fugir do porto de Mucuripe outra nau, matando-the alguns homens do batel, o que foi causa de que a 15 ou 16 léguas daqui fosse dar à costa: onde dizem, que se perdeu além da gente, muito marfim, e ouro da Costa da Mina, $[\ldots]^{97}$ meado). La Fleur (2000, p 83-102).

93. La Fleur (2000, p. 89).

94. Não consegui localizar essa última localidade.

95. La Fleur (2000, p. 78).

96. Segundo a revista National Geographic, entre 2010 e 2012, apesar de todos os esforços, cerca de 100 mil elefantes foram dizimados por caçadores clandestinos em toda a África, uma média aproximada de 30 mil elefantes ao ano. Se a remessa total for arredondada para corresponder a 3 mil elefantes, é possível calcular se esta é uma cifra significativa, mesmo considerando dados atuais. Ver: <http://news. nationalgeographic.com/ news/2014/08/140818-elephants-africa-poaching-cites-census>.

97. Academia (1812, p. 6). 
98. Bento Banha Cardoso expôs seu argumento em uma "Informação". Contratos do Congo e Angola, 1611 - Brásio (MMA-I, v. 6, doc. 7 , p. $16-20$; p. 18-19).

99. Brásio (MMA-I, v. 6, doc. 7 , p. 18).

100. Brásio (MMA-I, v. 6, doc. 7 , p. 19).
Essa embarcação trazia ouro da Costa da Mina e martim, cuja procedência, infelizmente, é impossível saber, assim como a rota completa da embarcação. As poucas viagens holandesas realizadas nos primeiros anos do século XVII são ainda pouco estudadas, assim como os circuitos comerciais utilizados pelos comerciantes de Amsterdã nas duas primeiras décadas do século XVI, antes da criação da WIC. O foco no comércio do marfim parece ser um caminho tanto para o comércio holandês, quanto para o comércio francês e português naquele período.

Loango e Angola nas primeiras décadas do século XVII

Em 1611 o rei de Portugal passa um regimento para o futuro governador de Angola, Francisco Correia. Correia não toma posse, sendo substituído por Bento Banha Cardoso, que governa Angola até 1615. Em agosto de 1611, Banha Cardoso redige uma "Informação" (tipo de relatório solicitado pelo Conselho Ultramarino) sobre uma proposta apresentada por João Salgado, visando separar o reino do Congo do reino de Angola, diminuindo assim a jurisdição de Angola. Sobre essa proposta, Bento Banha Cardoso escreve ao rei de Portugal, dizendo: "me pareceu que se devia entender os contratos, e não os governos". Banha Cardoso se contrapõe ao argumento de Salgado, defendendo a divisão dos contratos, mas não do governo. Em sua Informação apresenta as condições em que os contratos dos portos ao norte de Luanda deveriam ser lançados. Note-se que considera o marfim de Angola pouco representativo. ${ }^{98}$ Diz a Informação:

o contrato do Loango, Pinda, Maiombe e tudo o que está ao norte do Reino de Angola, desde o Rio Dande até o cabo de Lopo Gonçalves, e se arrende a parte, ou a pessoas que estejam cá, ou lá,.... o que se há de arrendar há de ser todo o gênero de coisas, tirado escravos, que suposto que nunca destes resgates saem, podem vir a sair por tempos, e farão falta no de Angola, aonde hoje vão arrebatar pelo sertão....

E também se deve tirar deste contrato os mantimentos porque esses são comuns a todos os que os querem resgatar e ficam resgatando marfim, panos de toda a sorte, xingos, que são cabelos de elefante, tacula, que é pau-vermelho e todas as miudezas que há por aquela costa.

Também se deve ajuntar a este contrato todo o marfim que se tira no distrito de Angola, que não é de muita importância, porque como os reinos de Congo e Angola partem pelo rio Dande, pode-se furtar o marfim de uns distritos para outros, e haver dúvidas entre os contratadores. 99

A Informação esclarece também sobre o lado sul da costa:

para barravento não há que tratar, que é a parte do Sul, porque dela não vem senão escravos, e pouco, e esses vem [sic] a sair pelo contrato de Angola. E o gado que lá se resgata não paga direitos, quanto mais que isso está dividido em outra capitania onde está Manoel de Cerveira e lá deve seguir a ordem que Sua Majestade the tiver dado. ${ }^{100}$

Banha Cardoso trata ainda da proposta de João Salgado para a construção da fortaleza portuguesa do Loango. Segundo ele, o Loango exigiria 
uma "nova conquista". Esclarece ainda que, para garantir a costa do Loango, não bastava uma fortaleza. Seria preciso evitar os negócios entre os comerciantes locais e as nações estrangeiras; e o único modo de atingir esse objetivo seria se fazendo "poderoso no Mar", de modo a evitar a navegação holandesa. ${ }^{101}$ Por isso defende o abandono do Loango e o investimento dos recursos disponíveis em Pinda, onde tinham o manicongo como aliado.

Esse episódio mostra a dificuldade de exercer qualquer domínio sobre os reinos do norte, e a diversidade de interesses políticos e comerciais envolvidos. A questão dos contratos e do governo traz à baila a abrangência da jurisdição do rei de Portugal sobre a foz do Zaire. Os contratos portugueses davam privilégios aos contratadores e restrições aos demais aos comerciantes portugueses em territórios que estavam fora dos domínios da Coroa de Portugal. Isso significa que seu cumprimento só tinha obrigatoriedade para os súditos da Coroa portuguesa. Se de um lado os vassalos do rei de Portugal tinham de se submeter a ele (especialmente os negociantes de Luanda), outras nações podiam livremente percorrer a costa e ignorar os estancos e contratos que só se aplicavam aos portugueses. O Maloango navega nessa difícil diplomacia, de um lado procura estar bem com os comerciantes portugueses, de outro garante o acesso de outras nações a seu porto, tirando assim o melhor proveito da situação.

Como já mostra Martin, embora holandeses, portugueses e outros comerciantes europeus convivessem, havia permanente disputa entre eles. A autora indica que em 1624 o governador de Angola, à época Fernão de Souza, manda mensagem ao Maloango para que seu porto fosse fechado aos holandeses que ali tinham uma feitoria. Em troca promete garantir mercadorias de melhor qualidade e comprar todo o suprimento de marfim, além de dar proteção contra os inimigos do Loango. Também, como de costume, um religioso católico poderia ser enviado. Todas as ofertas são rejeitadas. $\bigcirc$ Maloango continua seu comércio com os holandeses e informa não estar interessado em se fazer católico. ${ }^{102}$

Em 1620 foi lida pelo Conselho da Índia uma carta do bispo do Congo e Angola, na qual tratava mais uma vez da urgência da construção de uma fortaleza junto ao padrão de Pinda ou na llha dos Cavalos, ambos na foz do rio Zaire. ${ }^{103} \bigcirc$ bispo lembra que já tinha, sem sucesso, tentado negociar a referida obra, e argumenta que somente a presença constante dos portugueses poderia prevenir a constante entrada dos holandeses rio acima para comerciar escravos, marfim e mantimentos. Na carta adverte sobre a danosa presença holandesa, agravada pelo fato de serem hereges. Informa que os holandeses tinham quatro feitorias públicas em Pinda e nelas "muitas fazendas". E o pior, viviam ainda "semeando oras de Nossa Senhora falsificadas, bíblias em linguagem e livros articulados formalmente contra a Igreja Romana e doutrina evangélica". $\bigcirc$ bispo alegava ter-se empenhado sem sucesso em fazer o conde do Sonho despachar os holandeses, motivo
101. Um ponto importante da argumentação de Banha Cardoso é que a segurança da costa é indispensável mesmo sem o controle do território, único modo de garantir o cumprimento dos contratos. Para isso, como alternativa aos fortes sugeridos por João Salgado, sugere duas galeotas para o porto de Pinda que pudessem controlar o acesso ao rio, impedindo a entrada de estrangeiros. Brásio (MMA-I, v. 6 , doc. 7 , p. 19-20).

102. Sobre as tentativas de conversão do Maloango, ver Thornton (2002b, p. 89). Sobre os esforços de Fernão de Souza para reatar o comércio e converter o Maloango, ver Martin (1972, p. 50).

103. Cavalo marinho era a designação da época para hipopótamo. Agradeço a Joseph Miller a lembrança de que essa ilha foi refúgio para o Mani Congo em 1569, por ocasião de sua derrota frente aos Jagas. 
104. Consulta do Conselho da Índia sobre negócios do Pinda, 11/11/1620. Brásio (MMA-I, v. 15, doc. 184, p. 469-470).

105. O parecer de Luís Pereira lembrava que a obra da fortaleza "está começada e se tem metido nisto cabedal por parte da fazenda de V. Majestade". A rubrica do rei determinava que tudo fosse feito conforme o parecer do nosso já conhecido Simão Soares. Brásio (MMA-I, v. 15 , doc. 184 , p. 474).

106. Ver <http://www.sla vevoyages.org $>$; para análise dos dados, ver Sommerdyk (2012, p. 61, em especial gráfico 4 ).

107. Em nota ao documento, António Brásio informa que Francisco Correia da Silva não consta do Catálogo dos Governadores de Angola. Ao que parece, teria sido substituído por Dom Gonçalo Coutinho, que não tomou posse. Sobre as exportações de Benguela no século XVII e o comércio do cobre, ver Candido (2013, cap. 1).

108. Regimento do capitão e governador do Reino de Angola Francisco Correia da Silva. Brásio (MMA-I v. 6, doc. 8 , p. $32-33$ ) pelo qual "andavam os vassalos de V. Majestade oprimidos, e os hereges mimosos". Seu fracasso o levou a excomungar o conde que ficaria "interdito" até que voltasse atrás. $\bigcirc$ bispo descreve ainda a fraterna convivência entre os holandeses e a população local, dizendo que "logo ensinavam as suas heresias, e travavam com grande familiaridade os vassalos de V. Majestade, comendo e bebendo com eles, e sendo mais estimado do Conde e dos seus que os portugueses". 104 Os holandeses deixam Pinda no início da década de 1620; a excomunhão do manisonho é suspensa; e as relações entre Portugal e o Sonho se restabelecem. Quanto ao forte, pelo menos no papel a obra teria continuado. ${ }^{105}$

Os dados do banco de dados The Trans Atlantic Slave Trade Database mostram que os portos da costa do Loango entram no comércio de escravos a partir de meados do século XVII. ${ }^{106}$ Como mostra Sommerdyk, até 1600 o comércio de escravos nos portos da costa do Loango é muito pequeno (1.406 embarques registrados). Entretanto, o relato de Van den Broecke mostra que o comércio de marfim era significativo. Embora não se tenha ainda encontrado registros de comércio regular de marfim por parte de comerciantes portugueses na costa do Loango, tal atividade deve ser considerada. Em 1611 o item 23 do regimento do capitão e governador do Reino de Angola, Francisco Correia da Silva, datado de 22 de setembro de 1611 , autoriza a remessa de cobre de Benguela ao Brasil, mostrando que esses eram itens importantes do comércio. O cobre deveria ser embarcado "por lastro dos navios de escravos sem custar de frete coisa alguma". ${ }^{107}$ Já o marfim deveria ser considerado "outro resgate e de muita consideração em rendimento de muitos contos, pela grande quantidade que tem". ${ }^{108}$ Como é sabido que Angola produzia muito pouco marfim, a maior probabilidade é que essa "grande quantidade" fosse negociada em Pinda e no Loango, em concorrência com os franceses e holandeses.

Corroborando essa tese, embora não trate especialmente do comércio do marfim, a já citada Informação de Banha Cardoso mostra que a principal fonte de marfim eram as terras ao norte de Angola (Loango, Pinda e Maiombe) e que Portugal não tinha como evitar a concorrência estrangeira. Ao final da polêmica, Banha Cardoso não atinge seu intento: o contrato do Loango permanece vinculado ao de Angola. Por outro lado, a concorrência estrangeira e o descaminho entre os portugueses crescem ao longo do século. Mesmo sem números, é possível estimar a concorrência entre portugueses e holandeses no Loango; a predominância dos holandeses; e a disposição dos comerciantes e contratadores em manter, mesmo em condições adversas, seu comércio no Loango. Um exemplo dessa determinação é a presença do feitor do contrato naquele porto em 1603.

O comércio do marfim dá ao Loango um perfil diferente dos demais portos daquela costa, em especial Luanda e Benguela, que se concentram no comércio de escravos. Como mostra Sommerdyk, o comércio de escravos nos portos da costa do 
Loango, e no porto do Loango em particular, cresce inicialmente a partir da criação da WIC (1621) e mais tarde, na década de 1680, com a chegada dos ingleses e depois dos franceses. ${ }^{109}$ Uma outra particularidade do Loango, que acredito estar associada ao comércio do marfim, é o fato de ter conseguido, pelo menos até a década de 1620, manejar as pressões das nações europeias concorrentes entre si de modo a manter comércio tanto com holandeses quanto com portugueses. Por fim, praticando o comércio do marfim (em combinação com sal, panos de ráfia e outras mercadorias valorizadas no mercado local), o Loango investe em um comércio especializado e em uma forte rede comercial regional que ia da Malebo Pool a Angola. ${ }^{110}$ Os rendimentos desse comércio permitiram ao Loango ficar temporariamente fora do circuito dos escravos e das consequências disruptivas desse negócio.

No início do século XVII os holandeses ainda não tinham colônias, por isso se interessavam apenas por produtos que podiam comerciar na Europa. No Loango encontram marfim, cobre e tintas para tingir tecidos. Esses produtos, principalmente o marfim e a madeira, tinham ainda a vantagem de servir de lastro para os navios na viagem de volta. A chegada dos holandeses ao Loango no final do século XVI aumenta a demanda de marfim, e os comerciantes Vili do Loango ganham proeminência na foz do Zaire. Por outro lado, o fato de os portugueses progressivamente desistirem do controle do Loango em prol de Pinda faz que o Loango negocie mais livremente, com menor envolvimento com o comércio de escravos.

\section{Comentários finais}

A historiografia da costa ocidental africana tem-se concentrado nos "reinos" do Congo e Angola, explorando temas como o comércio lem particular de escravos), as guerras e a conversão dos gentios. Ao mesmo tempo, tem menosprezado o porto do Loango, onde nem uma nem outra coisa acontece até meados do século XVII. Um exemplo dessa quase invisibilidade são os dados do TSTDB, onde, como foi visto, não há registros de viagens ao Loango entre 1514 e 1600, e o primeiro embarque, tendo Loango como porto principal, data de 1642. No século XVII, excluído um único caso de conversão, os Maloangos se mantiveram afastados dos missionários e de todas as tentativas vindas do Congo e de Angola, para que aderissem à fé católica. Talvez por isso, ainda hoje, se saiba menos sobre eles que sobre os povos convertidos.

O fio condutor deste artigo é o comércio do marfim na costa centroocidental. $\bigcirc$ texto mostra as primeiras notícias por ocasião da chegada dos portugueses ao Congo, o começo do comércio no Loango, as tensões entre portugueses e holandeses, e finalmente o estabelecimento de um comércio regular no porto do Loango a partir dos últimos anos do século XVI com os portugueses, e em seguida com os holandeses que ali se estabelecem já na primeira década do século XVII. Entre 1490 e 1620 portugueses, franceses e holandeses frequentaram a costa centro-ocidental comprando marfim bruto. Vários registros mostram também
109. Sommerdyk (2012, p. 61 , gráfico 4). A primeira viagem registrada pelo TSTDB, tendo o Loango como principal porto de embarque de escravos, data de 1642, quando uma embarcação holandesa leva escravos do Loango a Pernambuco. Trata-se de uma embarcação holandesa chamada Diemen. A viagem teria começado em Luanda, comprado os escravos no Loango e seguido para Pernambuco, onde chegou em 4 de fevereiro de 1642 com 133 escravos dos 139 embarcados TSTDB viagem 11320.

110. Ao lado do marfim, os panos de ráfia foram uma importante mercadoria do comércio do Loango. No início do século XVII os portugueses estabeleceram um padrão para a circulação dos panos como moeda em Angola. Apenas os panos do Loango (libongo) e Congo (kundi) podiam circular como moeda. Os demais podiam ser usados apenas nas rotas de comércio do interior, fora do controle português. Hilton (1985, p. 77). O comércio dos panos de ráfia dá uma medida da importância da rede comercial do Loango. Segundo Beatrix Heintze, no século XVII havia três centros produtores de panos: Mbata (no Congo); Ocanga (no interior, geralmente combinado ao comércio do Congo); e o Loango. Na segunda metade do século XVII predominam os panos do Loango. Heintze (2007, Parte IV). Para os panos do Loango, ver especialmente Heintze (2007, p. 580-581). 
a circulação de marfim lavrado. $O$ estudo desses objetos hoje dispersos em museus de todo o mundo carece de um minucioso estudo sobre sua procedência e as condições em que o marfim circulava até chegar a seu destino final: as oficinas europeias, no caso do marfim bruto; e os museus e coleções particulares, no caso do marfim lavrado. Assim sendo, o presente artigo mostra o contexto histórico que permitiu a remessa de dentes de elefante - e junto com eles peças de marfim lavrado - do Congo e Loango para a Europa entre o final do século XV e as primeiras décadas do século XVII. A sistematização das informações disponíveis e uma leitura atenta de documentos ainda pouco explorados não são de menor importância já que, até hoje, não foi dada atenção ao tema.

\section{REFERÊNCIAS}

FONTES MANUSCRITAS

CARTA do doutor Gaspar Vaz dando parte ao rei que chegando ali um navio francês carregado de malagueta, marfim, algodão e courama... [s.1.], 4 set. 1531. Arquivo Nacional da Torre do Tombo, Corpo Cronológico, Parte I, maço. 47, nº 43.

\section{FONTES IMPRESSAS}

ACADEMIA Real das Sciencias. Catalogo dos governadores de Angola com uma previa noticia do principio da sua conquista e do que nella obrarão os governadores dignos de memoria. In: Noticias para a historia e geografia das nações ultramarinas, que vivem nos dominios portuguezes, ou lhes são visinhas. Lisboa: Tipografia da Academia Real das Sciencias, 1825. Tomo III da Colleção Notícias.

- Memorias para a historia da capitania do Maranhão. In: Noticias para a historia e geografia das nações ultramarinas, que vivem nos dominios portuguezes, ou lhes são visinhas. Lisboa: Tipografia da Academia Real das Sciencias, 1812, p. 1-120. Tomo I da Coleção Notícias. BARROS, João de. Da Asia de João de Barros e de Diogo de Couto... (nova edição). Lisboa: Regia Officina Typografia, 1778, v. 1.

BLUTEAU, Raphael. Vocabulario Portuguez \& Latino: aulico, anatômico, architectonico... Coimbra: Collegio das Artes da Companhia de Jesus, 1712-1728. 8 v. 
BRÁSIO, António (Ed.). Monumenta Missionária Africana. África Ocidental. Coligida e anotada pelo padre António Brásio. 1a série. Lisboa: Academia Portuguesa de História, 1981-1988. $15 \mathrm{v}$.

BRÁSIO, António (Ed.). Monumenta Missionária Africana. África Ocidental. Coligida e anotada pelo padre António Brásio. 2a série. Volumes I-IV. Lisboa: Agéncia Geral do Ultramar. 1958-1966; volumes V-VI Lisboa: Academia Portuguesa de História. 1979-1992; volume VII Lisboa: Centro de Estudos Africanos da Faculdade de Letras da Universidade de Lisboa. 2004. $7 \mathrm{v}$.

BRÁSIO, António (Ed.). Monumenta Missionária Africana. África Ocidental. Coligida e anotada pelo padre António Brásio. Suplemento aos séculos XV, XVI, XVII. Lisboa: Centro de Estudos Africanos da Faculdade de Letras da Universidade de Lisboa. 2004.

CADAMOSTO, Luiz. Navegação segunda de Luiz de Cadamosto. In: ACADEMIA Real das Sciencias. Noticias para a historia e geografia das nações ultramarinas, que vivem nos dominios portuguezes, ou lhes são visinhas. Lisboa: Tipografia da Academia Real das Sciencias, 1812, p. 59-72. Tomo II da Coleção Noticias.

GUILLAUMIN, Gilbert (Dir.). Ivoire. In: Encyclopédie du commerçant. Dictionaire du commerce et des marchandises, contenant tout ce que concerne le commerce de tèrre et de mer. Paris: Guillaumin et Cie. Éditeurs, 1841. Tome II.

JONES, Adams. Samuel Brun's voyages of 1611-20. In: German Sources for West African History, 1599-1669. Wiesbaden: Franz Steiner GMBH, 1983, p. 48-96.

LA FLEUR, James Daniel (Ed.) Pieter van den Broecke's Journal of Voyages to Cape Verde, Guinea and Angola (1605-1612). Translated and edited by J. D. La Fleur. London: The Hakluyt Society, 2000.

PINA, Rui de. No. IV. Chronica d'ElRey D. João II, escrita por Ruy de Pina, chronista mór de Portugal, e guarda mór da Torre do Tombo. In: Inéditos de Historia portuguesa da Academia de Ciências. Lisboa: Oficina da Academia de Real de Ciências, 1790/92, p. 5-204. Tomo II.

RAVENSTEIN, Ernest George (Ed.). The Strange Adventures of Andrew Battell of Leigh, in Angola and the Adjoining regions. Oxford: Hakluyt Society, 1901.

RESENDE, Garcia de. Chronica dos valoroses e insignes feytos del Rey Dom Joam II de gloriosa memoria, em que se refere sua vida, suas virtudes, seu magnanino esforço, excellentes costumes, \& seu christianissimo zelo. Lisboa: Officina de Manoel da Sylva, 1752.

SANTA MARIA, Agostinho de (frei). Santuário Mariano, e história das imagens milagrosas de Nossa Senhora. Lisboa: Officina de António Pedrozo Gaião, 1642-1728.

SILVA, Antonio Moraes e. Diccionario da lingua portugueza - recompilado dos vocabularies impressos ate agora, e nesta segunda edição novamente emendado e muito acrescentado. Lisboa: Typographia Lacerdina, 1813. $2 \mathrm{v}$. 
ZURARA, Gomes Eanes. Crónicas de Guiné. Segundo o ms. de Paris. Modernizada. Introdução, notas, novas considerações e glossário de José de Bragança. Barcelos: Livraria Civilização Editora, 1973.

\section{LIVROS, ARTIGOS, TESES E TEXTOS ON-LINE}

AFONSO, Luís Urbano; HORTA, José da Silva. Olifantes afro-portugueses com cenas de caça, c.1490-c.1540. Artis. Revista de História da Arte e Ciências do Patrimônio, Lisboa: FLUL, n. 1, p. 20-29, 2013.

ALENCASTRO, Luiz Felipe. Trato dos viventes. Formação do Brasil no Atlântico Sul. Séculos XVI e XVII. São Paulo: Companhia das Letras, 2000.

ALVES, Ana Maria. As entradas régias portuguesas. Uma visão de conjunto. Lisboa: Livros Horizonte, 1986, p. 25-49.

AXELSON, Victor. Portuguese in South-East Africa, 1480-1600. Johannesburg: C. Stuik (PTY) Ltd., 1973.

BASSANI, Ezio; FAGG, William. Africa and the Renaissance: Art in Ivory. Edited by Susan Vogel. New York/Houston: The Center for Africa Art/The Museum of Fine Arts, 1988.

BASSANI, Ezio. A note on Kongo high-status caps in old European collections. Res: Anthropology and Aesthetics, Chicago: University of Chicago, n. 5, p. 74-84, 1983.

BIRMINGHAN, David. Alianças e conflitos. Os primórdios da ocupação estrangeira em Angola, 1483-1790. Luanda: Arquivo Histórico de Angola/Ministério da Cultura, 2004.

BOSTOEN, Koen et al. Middle to Late Holocene Paleoclimatic Change and the Early Bantu Expansion in the Rain Forests of Western Africa. Current Anthropology, Chicago: University of Chicago, v. 56, n. 3, p. 354-384, jun. 2015.

BOXER, Charles R. Salvador de Sá e a luta pelo Brasil e Angola. São Paulo: Companhia Editora Nacional, 1973, p. 298.

CALVO, Francisco Nocete et al. The ivory workshop of Valencina de la Concepción (Seville, Spain) and the identification of ivory from Asian elephant on the Iberian Peninsula in the first half of the 3rd millennium BC. Journal of Archaeological Science, London, Mar. 2013, v. 40, issue 3, p. 1579-1592.

CANDIDO, Mariana. An African Slaving port and the Atlantic World. Benguela and its Hinterland. Cambridge: Cambridge University Press, 2013.

DEVEAU, Jean-Michel. L'or et les esclaves. Historie des fortes du Ghana du XVIe au XVIIIe siècle. Paris: Unesco/Karthala, 2005. 
FAGG, William. Afro-Portuguese Ivories. London: Batchworth Press, 1958.

FERREIRA, Roquinaldo. Transforming Atlantic Slaving: Trade, Warfare and Territorial Control in Angola, 1650-1800. Los Angeles, 2003. Ph.D. Dissertation. University of California.

GUIMARÃES, Cecília Silva. Um armazém de escravos no Atlântico: o comércio na Ilha de São Tomé - século XVI. In: 4O ENCONTRO ESCRAVIDÃO E LIBERDADE NO BRASIL MERIDIONAL. Curitiba: 13-15 maio 2009.

HECHT, Johanna. Ivory and Boxwood Carving, 1450-1800. In Heilbrunn Timeline of Art History. New York: The Metropolitan Museum of Art, 2000. Disponível em: <http://www. metmuseum.org/toah/hd/boxw/hd_boxw.htm>. Acesso em: 12 fev. 2017.

HEINTZE, Beatrix. Angola nos séculos XVI e XVII. Estudos sobre fontes, métodos e história. Luanda/Lisboa: Ed. Kilombelombe, 2007.

HENRIQUES, Isabel de Castro. São Tomé e Príncipe - A invenção de uma sociedade. Lisboa: Veja Editora, 2000.

HERBERT, Eugenia. Red Gold of Africa: Copper in Precolonial History and Culture. Madison: University of Wisconsin Press, 1984.

HILTON, Anne. The Kingdom of Kongo. Oxford: Clarendon Press, 1985.

MALLALIEU, Huon. História ilustrada das antiguidades. São Paulo: Nobel, 1999.

MARK, Peter. Towards a reassessment of the dating and the Geographical origins of the LusoAfrican Ivories, Fifteenth to seventeeth centuries. History in Africa, Cambridge, 2007, v. 34, p. 189-211.

MARQUES, António Henrique Rodrigo de Oliveira. História de Portugal. Lisboa: Palas Editores, $1984.3 \mathrm{v}$.

MARTIN, Phyllis. The External Trade of the Loango Coast, 1576-1870. The effect of Changing Commercial Relations on the Vili Kingdom of Loango. Oxford: The Clarendon Press, 1972.

MENDES, António de Almeida. Les réseaux de la traite ibérique dans l'Atlantique nord (14401640). Annales. Histoire, Sciences Sociales, Paris: 2008/4, p. 739-368.

MILLER, Joseph; THORNTON, John. The Chronicle as Source, History, and Hagiography: The "Catálogo dos Governadores de Angola". Paideuma, [s.1], 1987, v. 33, p. 359-89.

PAIVA, José Pedro. Os bispos de Portugal e do Império, 1495-1777. Coimbra: Imprensa da Universidade de Coimbra, 2006.

POSTMA, Johannes. The Dutch in the Atlantic Slave Trade, 1600-1815. Cambridge: Cambridge University Press, 1990. 
SCHULTZ, Kara Danielle. The Kingdom of Angola is not Very Far From Here: The Rio de la Plata, Brazil and Angola. Nashville, 2016. Ph.D. dissertation in History. Department of History, Vanderbilt University.

SERRÃO, Joel (Dir.). Dicionário de história de Portugal. Porto: Livraria Figueirinhas, s/d. 3 v.

SILVA, Filipa Ribeiro da. Dutch and Portuguese in Western Africa: States, Merchants and the Atlantic System, 1580-1674. Leiden: Brill, 2011.

SIMÕES, Catarina Santana. The Symbolic Importance of the "Exotic" in the Portuguese Court in the Late Middle Ages. Anales de Historia del Arte, Madrid, nov. 2014, v. 24, n. especial, p. 517-525.

SOMMERDYK, Stacey Jean Muriel. Trade and the Merchant Community of the Loango Coast in the Eighteenth Century. Hull, 2012. Ph.D. dissertion in Philosophy. University of Hull.

TAYLOR, Aline. Isabel of Burgundy: The Duchess who Played Politics in the Age of Joan of Arc, 1397-1471. Madison: Madison Books, 2001.

THE TRANS Atlantic Slave Trade Database. In: Emory University. Disponível em <www. slavevoyages.org $>$. [acesso em 24.03.2017]

THORNTON, John. African Political Ethics and the Slave Trade: Central African Dimensions. COLONIAL AND IMPERIAL HISTORIES COLLOQUIUM. Princeton: Princeton University, 2002a Dec. 11.

Religious and Cerimonial Life in the Kongo and Mbundu Areas, 1500-1700. In: HEYWOOD Linda (Ed.). Central Africans and Cultural Transformations in the American Diaspora. Cambridge: Cambridge University Press, 2002b, p. 71-89.

VANSINA, Jan. The Tio Kingdom of the Middle Congo, 1880-1892. Oxford: Oxford University Press, 1973.

Long-Distance Trade-Routes in Central Africa. The Journal of African History, Cambridge, 1962, v. 2, p. 375-590.

Paths in the Rain Forests. Towards a History of Political Tradition in Equatorial Africa. Madison: The University of Wisconsin Press, 1990.

Artigo apresentado em 28/10/2016. Aprovado em 20/02/2017. 